Article

\title{
Experimental Study on the Effectiveness of Inorganic Bonding Materials for Near-Surface Mounting Shear Strengthening of Prestressed Concrete Beams
}

\author{
Vikas Singh Kuntal ${ }^{1}$, M. Chellapandian ${ }^{2}\left(\mathbb{D}\right.$, S. Suriya Prakash ${ }^{2}\left(\mathbb{D}\right.$ and Akanshu Sharma ${ }^{3, *(\mathbb{D})}$ \\ 1 Department of Civil Engineering, University of Tokyo, Bunkyo 113-8654, Japan; vikas@iis.u-tokyo.ac.jp \\ 2 Department of Civil Engineering, IIT Hyderabad, Sangareddy 502285, India; \\ ce15resch11005@iith.ac.in (M.C.); suriyap@iith.ac.in (S.S.P.) \\ 3 Institute of Construction Materials, University of Stuttgart, Pfaffenwaldring 4G, 70569 Stuttgart, Germany \\ * Correspondence: akanshu.sharma@iwb.uni-stuttgart.de; Tel.: +49-711-685-68034
}

Received: 22 May 2020; Accepted: 14 June 2020; Published: 17 June 2020

\begin{abstract}
Use of organic resins such as epoxy and vinyl esters as bonding materials in fibre reinforced polymer (FRP) strengthening of concrete members is widely accepted. However, the performance of organic resins is compromised when exposed to high temperature and extreme weather conditions leading to reduced durability of the strengthened systems. The present study attempts to evaluate the effectiveness of inorganic (cement mortar and geopolymer mortar) bonding materials for shear strengthening of prestressed concrete (PSC) beams using the near-surface mounting (NSM) technique. Different types of bonding materials are used in this study for NSM shear strengthening including: (i) epoxy resin, (ii) high strength cement grout (HSCG) and (iii) geopolymer mortar. Bond tests were first conducted to evaluate the pull-out/bond strength of different bonding materials. Bond tests revealed that epoxy resin had the highest bond strength followed by geopolymer mortar and HSCG. Sixteen full-scale PSC beams were cast with and without stirrups. The beams were strengthened using NSM CFRP laminates oriented at 45-degree configuration and then tested under a three-point bending configuration. Experimental results revealed that the performance of high strength cement grout and geopolymer mortar was similar but with a lesser efficiency compared to the epoxy resin.
\end{abstract}

Keywords: inorganic bonding materials; geopolymer mortar; near surface mounting; prestressed concrete; shear strengthening

\section{Introduction}

Various fibre reinforced polymer (FRP) strengthening techniques like near-surface mounting (NSM), and external bonding (EB) have been widely adopted for improving the flexure and shear performance of reinforced concrete (RC) members [1-8]. The drawbacks of the EB techniques due to debonding can be avoided or reduced with the NSM technique. Unlike EB, the NSM technique does not change the aesthetics of strengthened concrete members. Significant advantages of using NSM over the EB strengthening include: (a) less propensity to debonding of FRP, (b) higher efficiency of strengthening due to better bonding, and (c) effective utilization of FRP. FRP reinforcement is more effectively engaged with higher efficiency in load resistance due to increased contact surface of the NSM FRP with the concrete substrate. The increased bond surface area in NSM strengthening also delays the possibility of FRP debonding failure when compared to EB strengthening.

The flexural behavior of prestressed concrete (PSC) members is well understood due to extensive experimental and analytical investigations in the past. However, the occurrence of shear failures varies widely with the sectional details, loading, and properties of the prestressed concrete beam. 
For this reason, there is no unique way to design for FRP shear strengthening [8-15]. Owing to these reasons, the shear behavior of FRP strengthened prestressed concrete members is not fully understood due to its complex nature and tendency to brittle failure [13-15]. Barros and Dias [15] studied the behavior of the NSM technique in shear strengthening for RC T-beams and found that NSM CFRP laminates oriented at $45^{\circ}$ resulted in better performance when compared to steel stirrup reinforcements. Ceroni [16] studied the shear strengthening with NSM CFRP bars and CFRP strips (EB technique) for RC members. The experimental results revealed the brittle nature and debonding of CFRP strips in the EB technique. However, in the case of NSM shear strengthening, good improvement in strength and ductility was observed. Rizzo and Lorenz [17] studied the effect of NSM FRP reinforcement on the shear strengthening of RC beams and concluded that a decrease in spacing of FRP or an increase in the inclination of bars did not improve the shear capacity of the specimens. Mofidi et al. [18] studied the retrofitting efficiency of T-beams under shear loading using NSM FRP rods. They found that NSM shear strengthening led to distributed cracking unlike control specimens with single shear cracks.

The type of bonding material (matrix or resin) used plays a significant role in the efficiency of FRP shear strengthening. Organic resins such as epoxy and vinyl esters are widely used as bonding materials in FRP strengthening of concrete members, however, inorganic resins possess numerous advantages over the organic resins; including: (a) better resistance against high temperatures, (b) improved UV resistance, (c) handling and use is simpler as the inorganic resins are water-based, (d) they emit no toxic smells during strengthening, and (e) comparable chemical bonding with concrete. When properly designed, it is possible to replace organic resins with inorganic ones for most strengthening applications [19-25]. Rahman et al. [19] studied the efficiency of cement mortar and epoxy resin as a bonding material for NSM strengthening. They found that the replacement of $50 \%$ epoxy with mortar resulted in better performance without altering the flexure dominant failure. Al-Mohammad et al. [20] studied the flexural strengthening of RC members using cement mortar and epoxy resin-based NSM strengthening. They found that both the bonding materials were effective in enhancing the flexural capacity of the strengthened beam. Many authors have tried to explore the bond behavior and shear transfer mechanisms of CFRP laminates with inorganic based bonding materials [21-25]. They concluded that good bond strength between the inorganic mortar and FRP is essential. Only a handful of studies in the past have focused on the use of inorganic bonding materials for NSM shear strengthening. For successful NSM shear strengthening, the bond between the NSM reinforcement and the concrete substrate is very critical. Thus, the aim of this study was to investigate the efficiency of different bonding materials on the NSM shear strengthening of high strength prestressed concrete beams.

\section{Research Methodology}

The review of past studies shows that the NSM shear strengthening of prestressed concrete beams with different bonding materials has not been explored in detail [26-31]. However, the effectiveness of organic resins such as epoxy and vinyl ester are compromised when exposed to elevated temperature and extreme weather conditions. The present study tries to evaluate the behavior of organic (epoxy) and inorganic (cement grout and geopolymer) bonding materials on the NSM shear strengthening of prestressed concrete beams. The efficiency of bonding material for NSM shear strengthening is evaluated based on its capability to: (i) improve the shear capacity, (ii) reduce the strains on stirrup reinforcements, and limit the shear crack widths and (iii) change the brittle shear failure mode to a more ductile flexural failure mode by modifying the hierarchy of strength. In this work, the efficiency of different bonding materials is evaluated in two stages. First, bond stress-slip behavior of different bonding materials is evaluated by performing pull-out tests. Second, full-scale tests on prestressed concrete beams NSM shear strengthened with different bonding materials is carried out to understand the improvement in overall behavior. 


\section{Experimental Program}

Apart from carrying out the pull-out tests, which will be reported later, in total, sixteen prestressed concrete beams were cast. As illustrated in Table 1, eight of these specimens had no stirrups in the test region (shear span ' $a$ ' $=625 \mathrm{~mm}$ ). The remaining specimens had two legged vertical stirrups of diameter $8 \mathrm{~mm}$ and placed at a spacing of $200 \mathrm{~mm}$ in the test region. All the beams had shear reinforcement outside the test region to limit the shear cracking and to localize the failure only in the test region. All the beams had a width of $150 \mathrm{~mm}$ and a depth of $300 \mathrm{~mm}$. The length of the beams was $1800 \mathrm{~mm}$ with an effective test span of $1650 \mathrm{~mm}$ (Figure 1). All the beams were strengthened using NSM technique but with different bonding materials. The details of the strengthening configuration and test details are given in Table 1. The previous study by the authors on NSM shear strengthening of PSC beams has shown that $45^{\circ}$ orientation of NSM laminates resulted in highest strength improvement without much compromise on ductility [5]. Therefore, only $45^{\circ}$ orientation of NSM laminates is considered for investigating the efficiency of different bonding materials on shear strengthening of prestressed concrete beams.

Table 1. Details of test specimens with different bonding materials.

\begin{tabular}{|c|c|c|c|c|c|}
\hline Specimen ID & $\begin{array}{l}\text { Number of } \\
\text { Specimens }\end{array}$ & $\begin{array}{l}\text { Presence of } \\
\text { Stirrups }\end{array}$ & $\begin{array}{c}\text { Shear Strengthening } \\
\text { Details }\end{array}$ & $\begin{array}{c}\text { Bonding } \\
\text { Material Used }\end{array}$ & $\begin{array}{c}\text { Orientation of } \\
\text { NSM }\end{array}$ \\
\hline Control & 2 & \multirow{4}{*}{ No } & No strengthening & - & - \\
\hline $\mathrm{C}+\mathrm{EP}+\mathrm{N} 45^{\circ}$ & 2 & & $\begin{array}{c}20 \mathrm{~mm} \times 1.4 \mathrm{~mm} \text { CFRP } \\
\text { laminates }\end{array}$ & Epoxy resin & $45^{\circ}$ \\
\hline $\mathrm{C}+\mathrm{CG}+\mathrm{N} 45^{\circ}$ & 2 & & $\begin{array}{c}20 \mathrm{~mm} \times 1.4 \mathrm{~mm} \text { CFRP } \\
\text { laminates }\end{array}$ & HSCG & $45^{\circ}$ \\
\hline $\mathrm{C}+\mathrm{GP}+\mathrm{N} 45^{\circ}$ & 2 & & $\begin{array}{c}20 \mathrm{~mm} \times 1.4 \mathrm{~mm} \text { CFRP } \\
\text { laminates }\end{array}$ & GP & $45^{\circ}$ \\
\hline $\mathrm{C}+\mathrm{S}$ & 2 & \multirow{4}{*}{ Yes } & No strengthening & - & - \\
\hline $\begin{array}{c}\mathrm{C}+\mathrm{S}+\mathrm{EP}+ \\
\mathrm{N} 45^{\circ}\end{array}$ & 2 & & $\begin{array}{c}20 \mathrm{~mm} \times 1.4 \mathrm{~mm} \text { CFRP } \\
\text { laminates }\end{array}$ & Epoxy resin & $45^{\circ}$ \\
\hline $\begin{array}{c}\mathrm{C}+\mathrm{S}+\mathrm{CG}+ \\
\mathrm{N} 45^{\circ}\end{array}$ & 2 & & $\begin{array}{c}20 \mathrm{~mm} \times 1.4 \mathrm{~mm} \text { CFRP } \\
\text { laminates }\end{array}$ & HSCG & $45^{\circ}$ \\
\hline $\begin{array}{c}\mathrm{C}+\mathrm{S}+\mathrm{GP}+ \\
\mathrm{N} 45^{\circ}\end{array}$ & 2 & & $\begin{array}{c}20 \mathrm{~mm} \times 1.4 \mathrm{~mm} \text { CFRP } \\
\text { laminates }\end{array}$ & GP & $45^{\circ}$ \\
\hline
\end{tabular}

Notes: C-Control beam; C + S-Beam with stirrups; N45-NSM laminates at $45^{\circ} ; \mathrm{HSCG}-$ High strength cement grout; GP-GGBS based Geopolymer mortar.

\subsection{Material Properties}

\subsubsection{Concrete}

The specimens were cast at a local precast industry company using the pre-tensioning process. The concrete mix was designed to reach a target cubic compressive strength of $60 \mathrm{MPa}$. The mix proportions used for concreting is as follows $\left(\right.$ in $\mathrm{kg} / \mathrm{m}^{3}$ ): cement—428; Fly ash—22; fine aggregate-728; coarse aggregate-1109; water-128; and admixture-2.5. Before concreting, the strands were stretched individually for a maximum prestressing force of $100 \mathrm{kN}$ (corresponding stress $=1013 \mathrm{MPa}$ ). Prestressing was released after seven days of curing. The maximum compressive stress developed in concrete at the stage of strand release was $13.32 \mathrm{MPa}$. After the release of prestress, the specimens were water-cured in a large curing tank for a period of 28 days. The compressive strength of the concrete, which is one of the most important parameters, was evaluated by testing standard cubes of size $150 \mathrm{~mm}$ and cylinders of size $150 \mathrm{~mm} \times 300 \mathrm{~mm}$. The loading rate for testing the samples was kept as $140 \mathrm{~kg} / \mathrm{cm}^{2}$ [32]. The values determined correspond to the average obtained by testing at least five samples and the actual values were reported along with the standard deviation (S.D). The mean cylinder and cubic compressive strength of concrete was found to be $52 \mathrm{MPa}$ (S.D = 1.16 MPa) and $65 \mathrm{MPa}(\mathrm{S} . \mathrm{D}=2.25 \mathrm{MPa})$, respectively. 

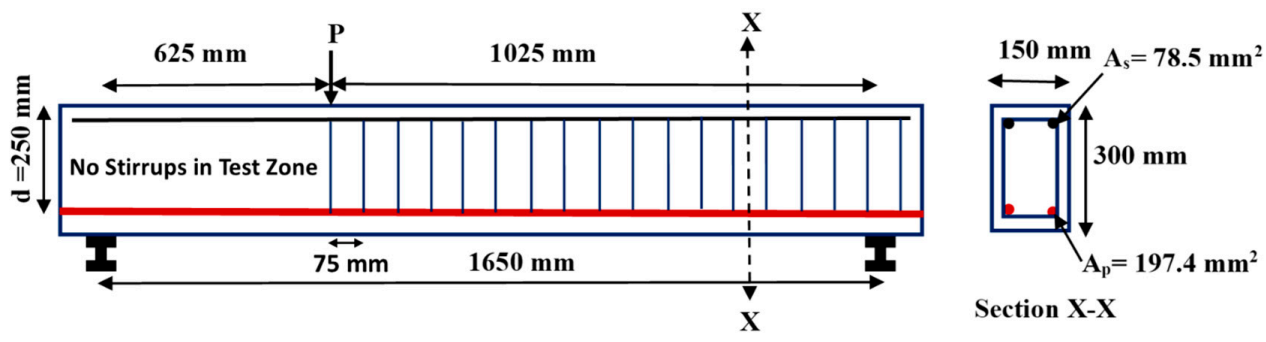

(a)
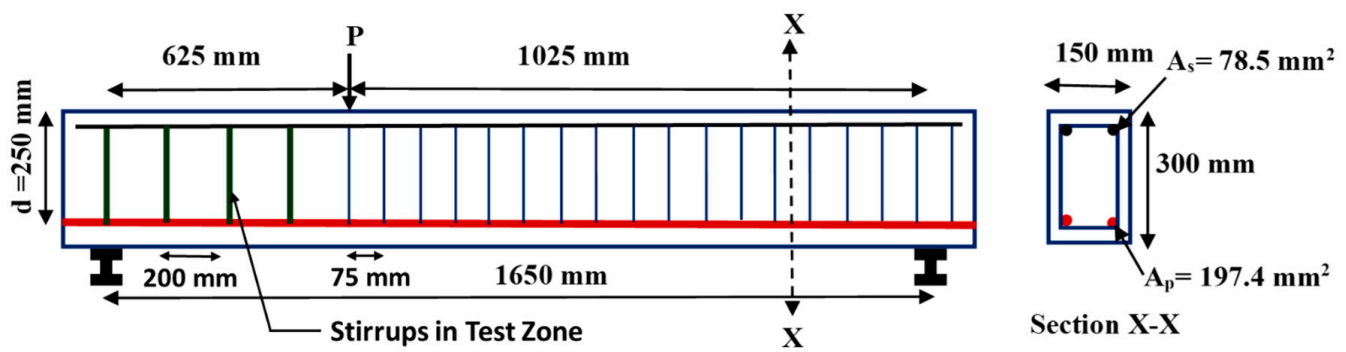

(b)

Figure 1. Sectional details of PSC beams. (a) Beams with no stirrups (in the test region); (b) Beams with stirrups (in the test region).

\subsubsection{Steel Reinforcement and Prestressing Tendons}

Two numbers of seven-wire prestressing strands were used as the longitudinal reinforcement for the beams. The strand used for prestressing is of $12.7 \mathrm{~mm}$ diameter with an effective area of $99.7 \mathrm{~mm}^{2}$. Coupon specimens were prepared for testing the prestressing strands under tension. The specimens were tested using a servo-controlled fatigue testing machine of $500 \mathrm{kN}$ capacity. The average ultimate strength and elastic modulus of the strands were found to be $1860 \mathrm{MPa}$ and $196 \mathrm{GPa}$, respectively. Two steel reinforcements of $8 \mathrm{~mm}$ diameter were used in the compression side of the beam. The vertical stirrups used were of $8 \mathrm{~mm}$ diameter spaced at a spacing of $75 \mathrm{~mm}$ on one side of the beam (Figure 1). The shear dominant zone of the beams had vertical stirrups at a spacing of $200 \mathrm{~mm}$ for eight specimens to understand the influence of stirrups on the performance of NSM shear strengthening. The ultimate strength and rupture strain of the steel reinforcements obtained from the tension test was $512 \mathrm{MPa}$ and $7.8 \%$, respectively.

\subsubsection{Carbon FRP Laminates}

For strengthening the prestressed concrete beams in shear, Carbon FRP laminates were used $(20 \mathrm{~mm} \times 1.4 \mathrm{~mm})$. The schematic representation of the setup used for strengthening PSC beams under shear is depicted in Figure 2. For understanding the material characterization of the carbon laminates, the composite coupons were tested using a fatigue testing machine (servo-controlled) as per ASTM standards [33]. The elastic modulus, tensile strength and rupture strain of CFRP coupons were found to be $150 \mathrm{GPa}, 2300 \mathrm{MPa}$, and $1.3 \%$ respectively. 


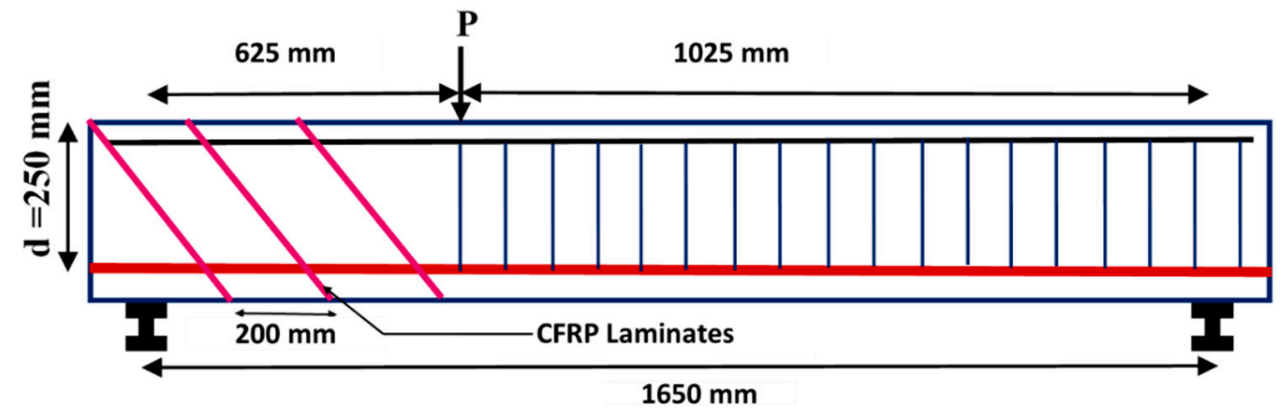

(a)

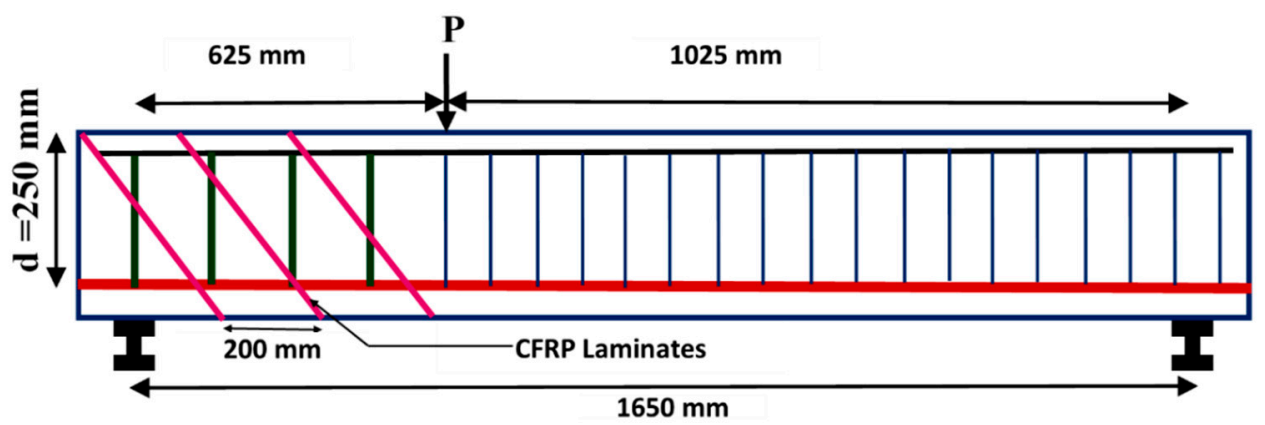

(b)

Figure 2. Schematic of loading details for NSM shear strengthened PSC beams. (a) Beams with no stirrups (in the test region); (b) Beams with stirrups (in the test region).

\subsection{Pull-Out Tests on Different Bonding Materials}

\subsubsection{Background}

The bond strength between FRP and concrete is a key factor controlling debonding failure modes in NSM FRP strengthening. Several experimental and analytical studies in the past have investigated bonding mechanisms and were generally based on single and double shear tests. The modified beam tests considering the effect of the flexural cracks on the bond performance of the FRP-to-concrete interface were rarely used. The bond between NSM circular bars and the concrete substrate has been investigated previously $[34,35]$. In this study, simple pull-out tests were carried out to determine the bond strength and failure mode of different bonding materials. Detailed bond studies for different parameters such as: (i) dimensions of the laminates, (ii) embedment length, (iii) cover thickness to NSM laminates and (iv) concrete strength are outside the scope of this study. The objective of this pull-out test is to assess the bond strength of organic and inorganic bonding material by simple means before the full-scale testing of NSM strengthened beams.

\subsubsection{Specimen Preparation}

Three different bonding materials, namely epoxy resin, high strength cement grout (HSCG) and geopolymer mortar (GP) were used for NSM shear strengthening. High strength cement grout was obtained from the local supplier which corresponds to the quick-set non-shrink grout used for repair works. The auxiliary cubes prepared from the samples of HSCG showed $45 \mathrm{MPa}$ and $60 \mathrm{MPa}$ compressive strength at 7 days and 28 days of ambient curing. Epoxy resin refers to the conventional two component based chemical bonding material (base and hardener) used for majority of the strengthening applications. For the preparation of geopolymer mortar, the cement was completely replaced with ground granulated blast furnace slag (GGBS) obtained from a local supplier. The material characterisation tests were performed for GGBS and the values of specific gravity, fineness modulus 
and bulk density were $2.98,1490 \mathrm{~kg} / \mathrm{m}^{3}$ and 2.40, respectively. Repair mortar was prepared by mixing both GGBS and sand in equal proportions (GGBS:Sand =1:1). The slag in the mortar mix was activated by the addition of sodium hydroxide $(\mathrm{NaOH})$ and sodium silicate $\left(\left(\mathrm{Na}_{2} \mathrm{SiO}_{3}\right)\right.$ solution which results in geopolymerisation. The average cubic compressive strength of the mortar was found to be $35 \mathrm{MPa}$ at 7 days of air curing. The resins used for strengthening of structural assets will experience predominant ambient curing conditions and are less likely to experience elevated temperatures. Hence, the GP mortar specimens were cured under ambient curing conditions rather than the oven curing method.

The samples for pull-out tests were prepared by casting standard cubes of size $150 \mathrm{~mm}$ with the provision for placing laminates at the centre (Figure 3). The dimensions of the laminates used for bond test were $20 \mathrm{~mm} \times 1.4 \mathrm{~mm}$. The dimensions of the hole were kept 1.5 times the dimensions of the laminates as prescribed in the code ASTM C1583 [36]. For each series, three samples were tested to verify the repeatability of results. Auxiliary specimens like cubes and cylinders were also cast and tested to determine the compressive strength of the bonding materials.

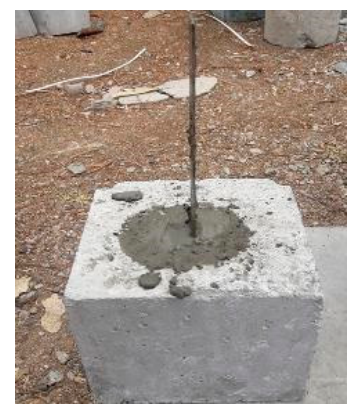

(a)

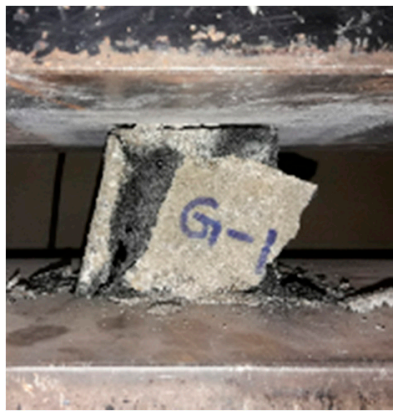

(b)

Figure 3. Sample preparation and compression behavior of bonding materials. (a) Prepared sample for bond test; (b) Compression tests on mortar cubes.

\subsubsection{Test Setup and Results}

The test setup used for determining the bond properties of different materials is shown in Figure 4. The bond test is carried out using a servo-controlled tension testing machine. The embedded laminates were pulled out in a displacement-controlled mode at a slow loading rate of $1 \mathrm{~mm} / \mathrm{min}$. A Linear Variable Displacement Transducer (LVDT) is mounted on the CFRP laminates to measure the slip (pull out) from the embedded cube specimen. A Data Acquisition System (DAQ) is used to collect the load and deformation output during the testing.

The typical load-pull out displacement of specimen bonded using different materials is illustrated in Figure 5, while the typical failure modes are depicted in Figure 6. Epoxy resin has been extensively used as a bonding material due to its superior mechanical and bond properties. For the specimens bonded using epoxy resin, splitting of cube occurred prior to the debonding failure of FRP and the average equivalent bond stress was limited to a value of $8.7 \mathrm{MPa}(29.9 \mathrm{kN})$. The laminates had slippage at a debonding strain of 0.0061 (standard deviation $=0.00018$ ).

The specimens with HSCG as bonding materials were tested to determine the bond stress and debonding strain. The load-pull out displacement of HSCG bonded specimen is illustrated in Figure 5. The specimens had average bond stress and debonding strain of $1.3 \mathrm{MPa}(4.5 \mathrm{kN})$ and 0.0026 (standard deviation $=0.0005$ ), respectively. The failure of specimens occurred due to interfacial slip (friction pull out) of CFRP laminates as shown in Figure 6.

The load-pull out displacement of GP bonded CFRP specimen is illustrated in Figure 5. The average bond stress and debonding strain of CFRP laminates were found to be $0.73 \mathrm{MPa}$ and 0.0020 (standard deviation $=0.0004$ ), respectively. The bond strength of GP mortar was found to be the least when compared to the other bonding materials. The failure occurred due to interface friction (pull-out) of laminates (Figure 6). 


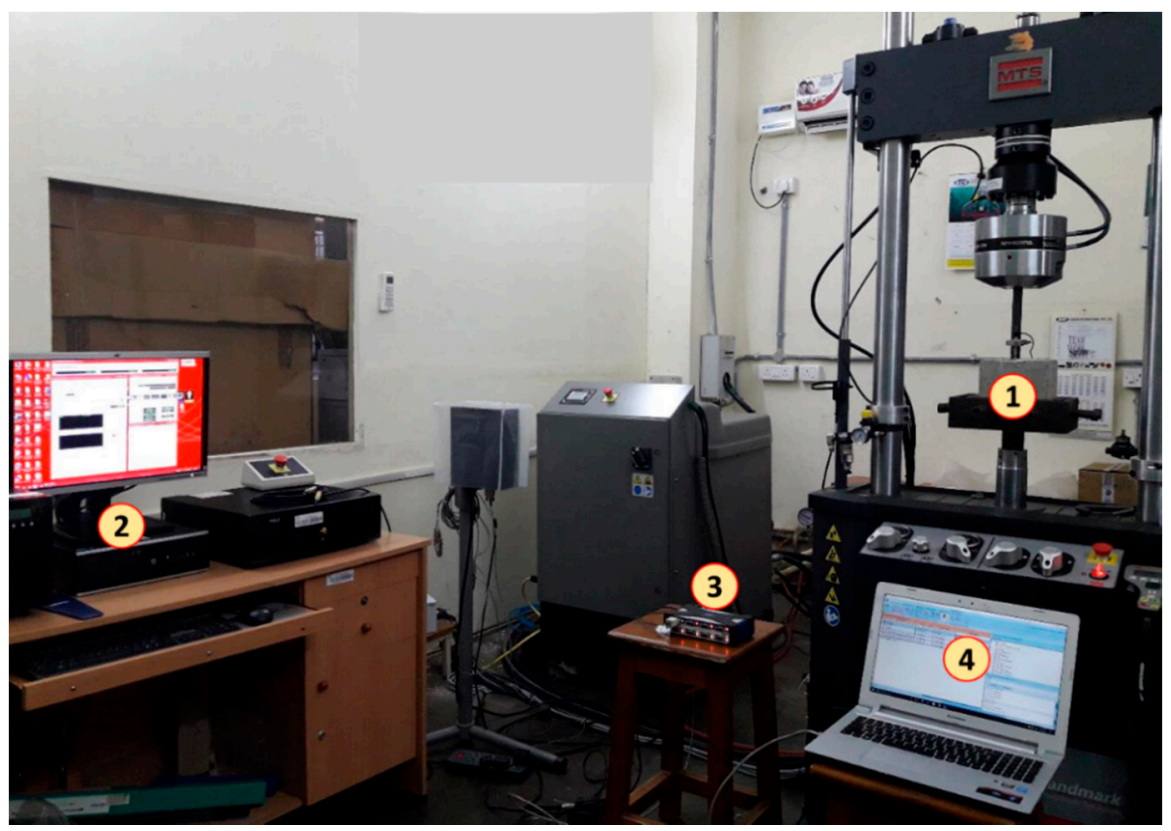

Figure 4. Test setup and instrumentation for bond tests. Components: (1) Test specimen, (2) Controls system, (3) DAQ, (4) Operating system.
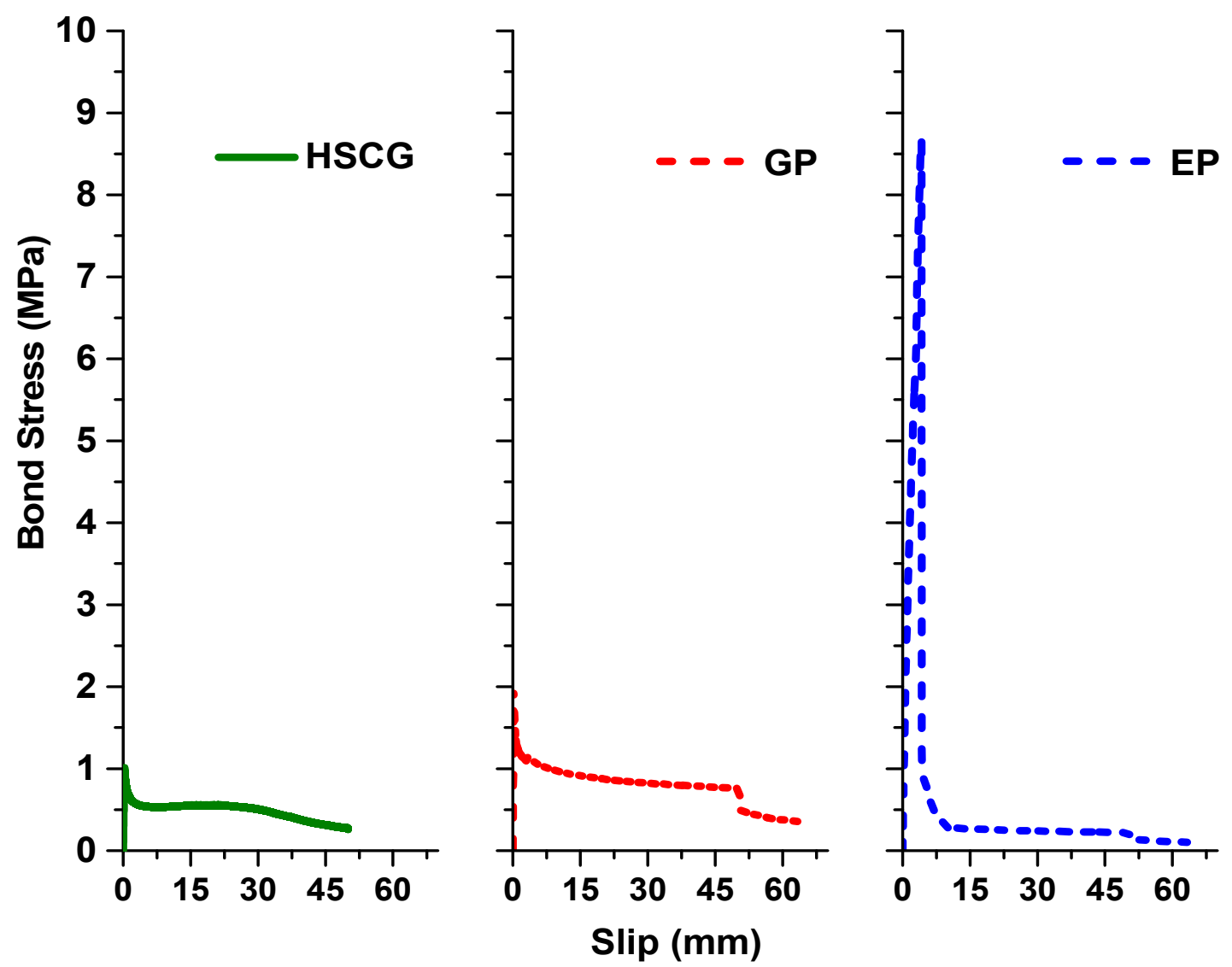

Figure 5. Shear stress vs. slip of different bonding materials. 


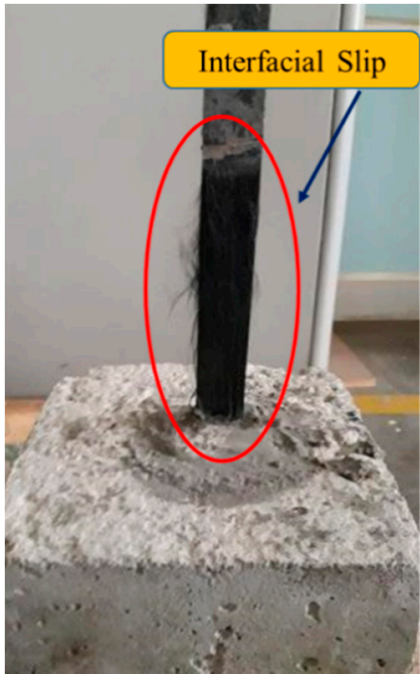

(a)

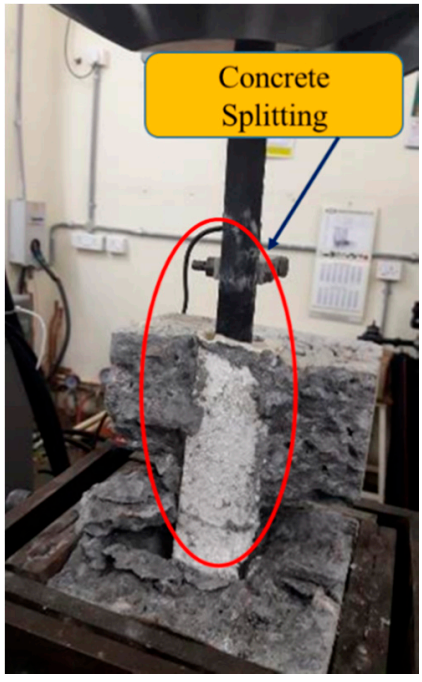

(b)

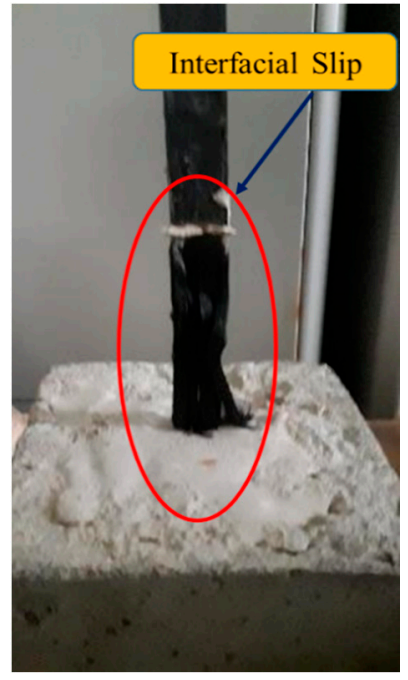

(c)

Figure 6. Failure mode of different bonding materials. (a) HSCG mortar; (b) Epoxy resin; (c) GP mortar.

\subsubsection{Bond Strength from Analytical Calculations}

Previously developed equations $[37,38]$ were used for determining the bond strength of FRP with different bonding materials. Teng et al. [37] developed an equation from a simple shear test for calculating the peak bond stress of FRP. The calculated values are compared with the experimental results in Table 2 . The experimental results and the analytical predictions for different bonding materials had a fair correlation. The bond stress values for HSCG and GP mortar were over-predicted by the analytical equations (Table 2). This is attributed to the fact that Equation (1) through Equation (4) are valid for the debonding failure where the force coming from FRP cannot be sustained by the concrete substrate. In the other two cases, due to relatively low bond strength, the failure occurs by peeling off FRP at the interface due to insufficient shear (bond) strength of the mortar. Nevertheless, further work is required to verify whether these equations are also applicable for predicting the strength corresponding to debonding failure in case of HSCG and GP mortar. Description of all the variables are given in nomenclature at the end of the paper.

Table 2. Comparison of bond strengths for different bonding materials.

\begin{tabular}{|c|c|c|c|c|c|}
\hline \multirow{2}{*}{ Specimen ID. } & \multirow{2}{*}{ Average Peak Load (kN) } & \multicolumn{2}{|c|}{ Peak Shear Stress (MPa) } & \multirow{2}{*}{ Debonding Strain } & \multirow{2}{*}{ Failure Mode } \\
\hline & & Experiment & Analytical & & \\
\hline $\mathrm{EP}$ & 29.9 & 8.70 & 8.73 & 0.0061 & $\begin{array}{l}\text { Concrete } \\
\text { Splitting }\end{array}$ \\
\hline GP & 2.50 & 0.73 & 2.80 & 0.0020 & Interfacial Slip \\
\hline HSCG & 4.50 & 1.30 & 3.40 & 0.0026 & Interfacial Slip \\
\hline
\end{tabular}

The stress in the FRP laminates $\left(\sigma_{p}\right)$ calculated using Equation (1):

$$
\sigma_{p}=\alpha \beta_{P} \beta_{L} \sqrt{\frac{E_{P} \sqrt{f_{\mathcal{c}}^{\prime}}}{t_{P}}}
$$

where $E_{P}$ is the modulus of elasticity of FRP laminates (MPa); $t_{P}$ is the thickness of FRP laminates (mm); $b_{P}$ is the width of FRP laminates $(\mathrm{mm}) ; b_{c}$ is the width of concrete cube $(\mathrm{mm}) ; f^{\prime}{ }_{c}$ is the compressive strength of the bonding material (MPa); $\alpha$ is an empirical parameter. 
The value of parameters $\beta_{P}$ and $\beta_{L}$ is calculated using Equations (2) and (3):

$$
\begin{gathered}
\beta_{P}=\sqrt{\frac{2-\frac{b_{P}}{b_{c}}}{1+\frac{b_{P}}{b_{c}}}} \\
\beta_{L}=\left\{\begin{array}{c}
1 \text { if } L \geq L_{e} \\
\sin \frac{\pi L}{2 L_{e}} \text { if } L<L_{e}
\end{array}\right.
\end{gathered}
$$

where ' $L$ ' is the embedment length of FRP in ' $m m^{\prime}$ '. The effective length $\left(L_{e}\right)$ of the FRP laminates is calculated as follows:

$$
L_{e}=\sqrt{\frac{E_{P} t_{P}}{\sqrt{f_{c}^{\prime}}}}
$$

\section{Full Scale Tests on Beams with NSM Shear Strengthening}

\subsection{NSM Shear Strengthening Procedure}

NSM shear strengthening was carried out as per ACI 440.2R provisions [39]. The laminates were oriented at an angle of $45^{\circ}$ as it was found to be the most efficient orientation in the previous studies [5,11-13]. The dimensions of grooves were prepared not lesser than 1.5 times the dimensions of reinforcing materials used [39]. The grooves dimensions used were $30 \mathrm{~mm} \times 3 \mathrm{~mm}$. The grooves were cleaned using high jet water spray to drive out the dust particles. After thorough cleaning, primer resin was applied on the surface (hardener: base $=1: 2$ ) to improve the bond efficiency. Thereafter, the bonding materials were prepared and transferred into the grooves. The bonding material used were two component-based epoxy resin, HSCG and the GP mortar. The CFRP laminates were pressed against the bonding materials and then the surface finishing was carried out. After a minimum curing period of seven days, the specimens were tested as presented in the subsequent sections. The systematic procedure for NSM strengthening is shown in Figure 7.

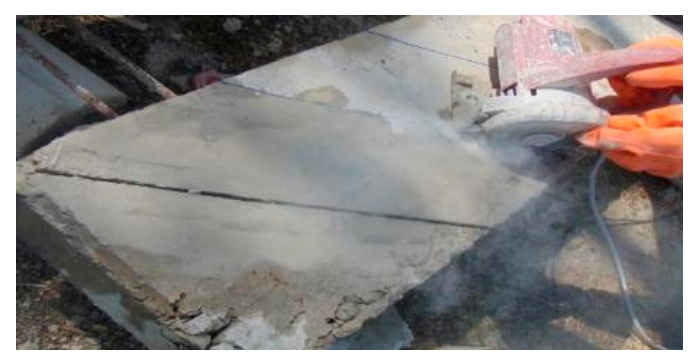

(a)

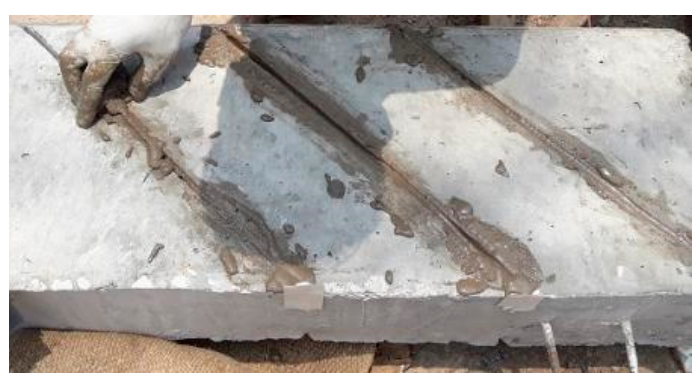

(c)

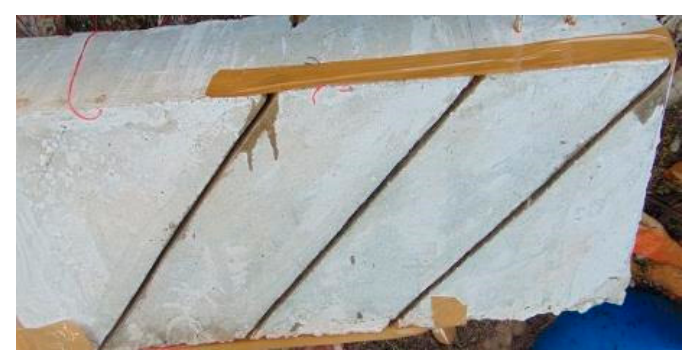

(b)

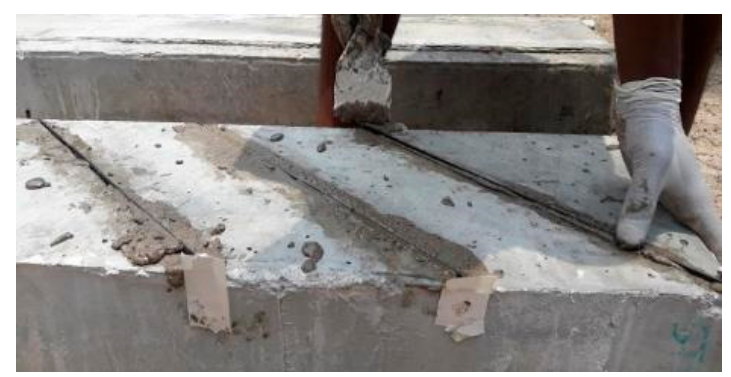

(d)

Figure 7. Step by step procedure for NSM strengthening of PSC beams. (a) Grooving of PSC beams; (b) Primer application in grooves; (c) Placing the bonding materials and (d) Pressing CFRP laminates on grooves. 


\subsection{Test Setup and Instrumentation Details}

The test setup and the instrumentation details are illustrated in Figure 8. Kani [40] investigated the effect of different shear span to depth ratios on the shear behavior of RC beams. They reported a transition point for the shear span to depth ratio $(\mathrm{a} / \mathrm{d})$ of 2.5 at which the specimens will be critical in shear and the corresponding ultimate moment will be minimum. For a/d values less than 2.5, the specimens were found to develop the arch action. Moreover, for shear span to depth ratio between 2.5 and 5 , the failure was found to occur by diagonal shear tension mode. Thus, a/d ratio of 2.5 was considered in the study to have shear dominated behavior. All the beams were tested in a three-point loading configuration.

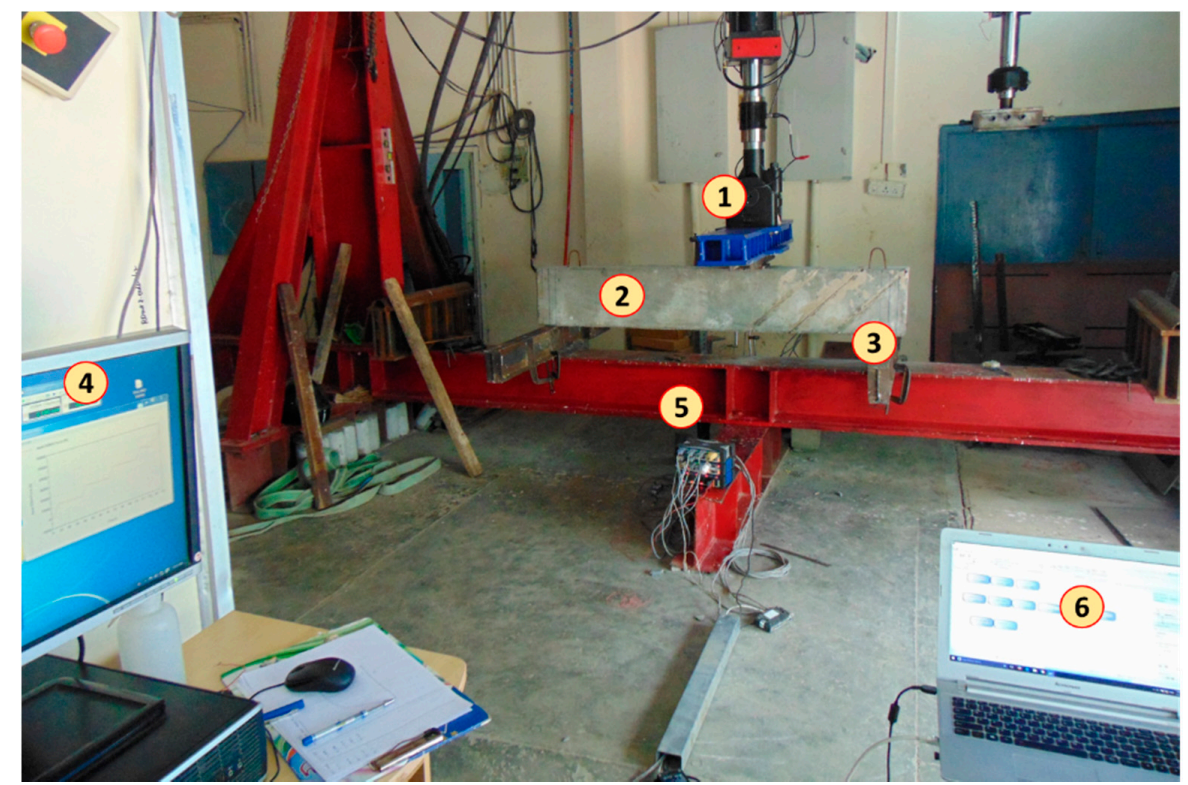

(a)

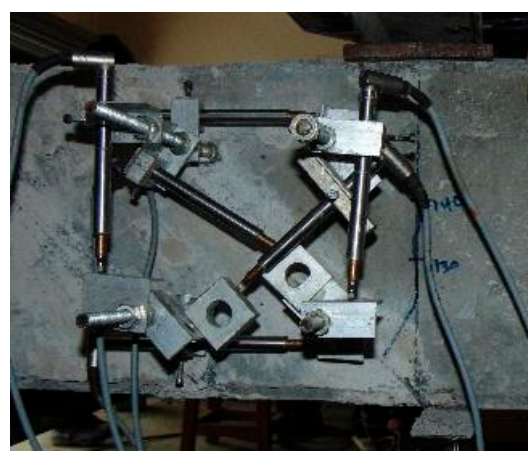

(b)

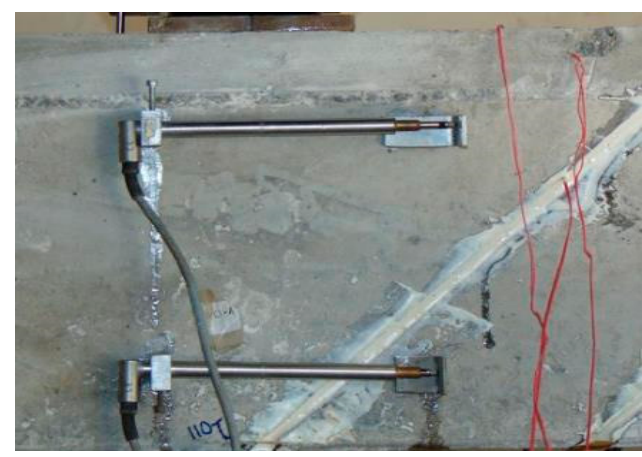

(c)

Figure 8. Test setup and Instrumentation details under shear loading. (a) Test setup for shear loading; (b) LVDT's for principal strain and (c) LVDT's for curvature measurement. Components: 1. $250 \mathrm{kN}$ MTS actuator; 2. Test specimen; 3. Support beam; 4 . Controls system; 5. DAQ system; 6. Operating system.

The load was applied monotonically in displacement-controlled mode using a $250 \mathrm{kN}$ servo-controlled actuator at a loading rate of $0.05 \mathrm{~mm} / \mathrm{s}$. The load from the actuator was transferred to the spreader beam which in turn transfers the load to the single I-beam to develop shear loading (Figure 8). The loading beam was placed at a distance of $625 \mathrm{~mm}$ from the right side support. The effective length of the specimen between the centre line of supports was $1650 \mathrm{~mm}$. The loading was paused intermittently at approx. every $10 \mathrm{kN}$ till peak load to mark the crack propagation. It is worth mentioning that no significant increase/decrease in deformations were noticed irrespective of the type of specimen tested during the investigation. 


\section{Results and Discussion}

\subsection{Load-Displacement Behavior}

The load-displacement behavior of PSC beams with and without NSM strengthening techniques is depicted in Figure 9. The failure or ultimate displacement of the specimen is defined as the displacement which corresponds to the load drop by more than $20 \%$ from the peak load or when the specimen fails in an abrupt manner. Similarly, the value of energy absorption is calculated by integrating the area under the load-displacement curve until the ultimate displacement. The control beam had an average load-carrying capacity of $144 \mathrm{kN}$. The specimens failed at an average displacement of $27 \mathrm{~mm}$ in a brittle shear tension mode. The NSM strengthened PSC beams at an orientation $45^{\circ}$ exhibited better performance in improving the overall behavior of PSC beams. The specimens with epoxy bonding $\left(\mathrm{C}+\mathrm{EP}+\mathrm{N} 45^{\circ}\right)$ attained an average peak load of $225 \mathrm{kN}$ corresponding to an average displacement of $25 \mathrm{~mm}$. The strengthening scheme was efficient in arresting the diagonal shear cracks and converted the failure mode from shear to flexure. The specimens had an ultimate displacement of $36.6 \mathrm{~mm}$ after which the testing was stopped due to failure. The NSM strengthened specimen with epoxy as bonding material had improvement in strength and ultimate displacement about $56.2 \%$ and $35.6 \%$. NSM strengthening with high strength cement mortar as the bonding material $\left(\mathrm{C}+\mathrm{HSCG}+\mathrm{N} 45^{\circ}\right)$ exhibited an average peak strength and ultimate displacement of $188 \mathrm{kN}$ and $39.2 \mathrm{~mm}$. The improvement in peak strength and ultimate displacement values were 30.5\% and $45.2 \%$ when compared to the control PSC beams. However, the beams were not able to resist the horizontal shear crack and had diagonal shear tension failure mode. It is worth mentioning that there was debonding of CFRP observed during the failure load of the specimen. In this series, the behavior of only one specimen is plotted due to instrumentation error in the measurements during test progress. Nevertheless, the peak load and the failure mode are found to be similar to the other specimen which is reported in Table 3. NSM strengthened specimens with geopolymer mortar $\left(\mathrm{C}+\mathrm{GP}+\mathrm{N} 45^{\circ}\right)$ as the bonding material had an average peak load capacity of $208 \mathrm{kN}$ corresponding to the displacement of $22.9 \mathrm{~mm}$. GP mortar was found to be highly effective in resisting the propagation of shear cracks and delayed the occurrence of possible shear failure. The specimens had a larger ultimate displacement of nearly $45 \mathrm{~mm}$ which is $66.7 \%$ higher when compared to the control specimens. The specimens restrained the possible debonding of FRP and had flexure failure mode which is considered to be an important observation from this research work.

The behavior of PSC beams with the presence of vertical shear reinforcements are shown in Figure 10. The control beams with stirrups had an average load-carrying capacity of $197 \mathrm{kN}$ corresponding to a displacement of $21.9 \mathrm{~mm}$. The provision of stirrups in the beam changed the failure mode from shear to flexure-shear. Moreover, the shear crack propagation in the shear span of the beams was effectively resisted. The beam had a failure at a displacement of nearly $35 \mathrm{~mm}$. The NSM strengthened stirrup beam using epoxy as the bonding material $\left(\mathrm{C}+\mathrm{S}+\mathrm{EP}+\mathrm{N} 45^{\circ}\right)$ failed under flexure with an average peak load capacity of $226 \mathrm{kN}$ which is $14.8 \%$ higher when compared to the stirrup beam without strengthening. However, the ultimate displacement of the specimen was reduced by about $14 \%$. The NSM strengthened stirrup specimens with HSCG as bonding materials $\left(\mathrm{C}+\mathrm{S}+\mathrm{HSCG}+\mathrm{N} 45^{\circ}\right)$ exhibited marginal improvement in strength with a reduction in ultimate displacement. The NSM strengthened stirrup specimens with GP mortar as bonding materials $(C+S$ $\left.+\mathrm{GP}+\mathrm{N} 45^{\circ}\right)$ exhibited negligible improvement in peak load capacity $(0.6 \%)$. Nevertheless, the GP mortar resisted the propagation of shear cracks and failed at a larger displacement with improved ductility. The important observation from this experimental work was that there is an interaction between internal stirrups and NSM laminates in shear resistance. Therefore, NSM strengthening of PSC beams with shear reinforcements was found to be less efficient in improving the load capacity. However, the addition of NSM laminates improved the ductility and ultimate displacement at failure. 


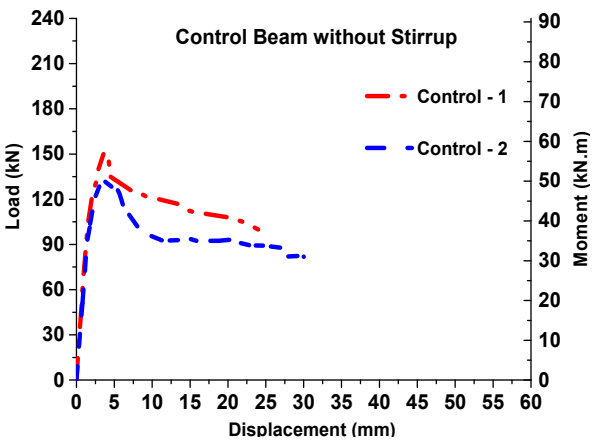

(a)

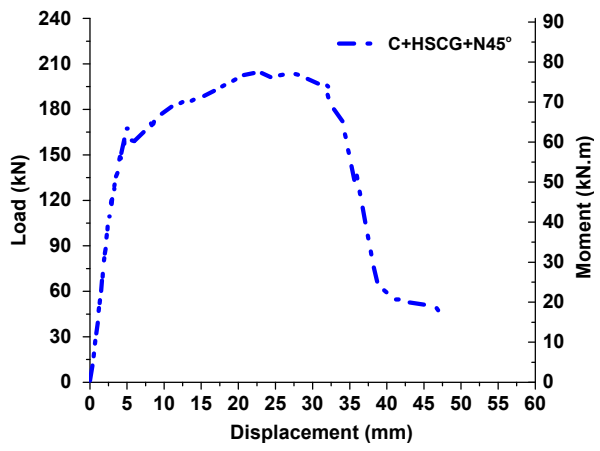

(c)

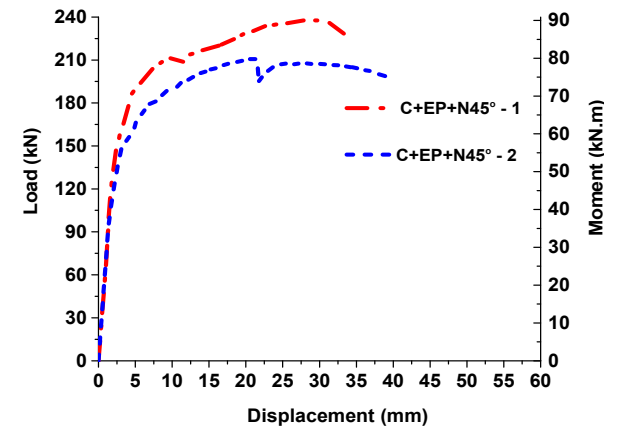

(b)

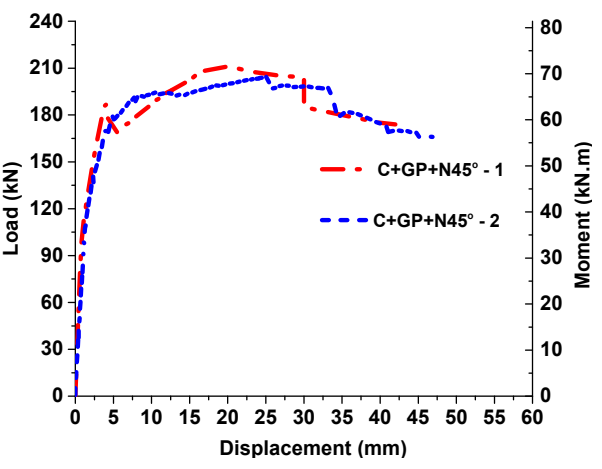

(d)

Figure 9. Behavior of NSM strengthened beams with different bonding materials. (a) Control beam; (b) Epoxy bonded specimen; (c) HSCG bonded specimen and (d) GP bonded specimen.

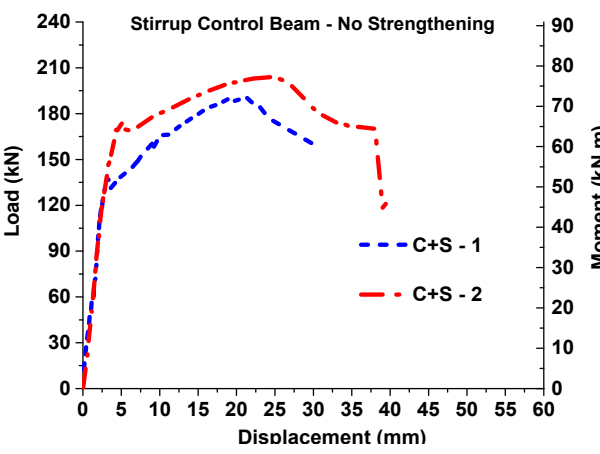

(a)

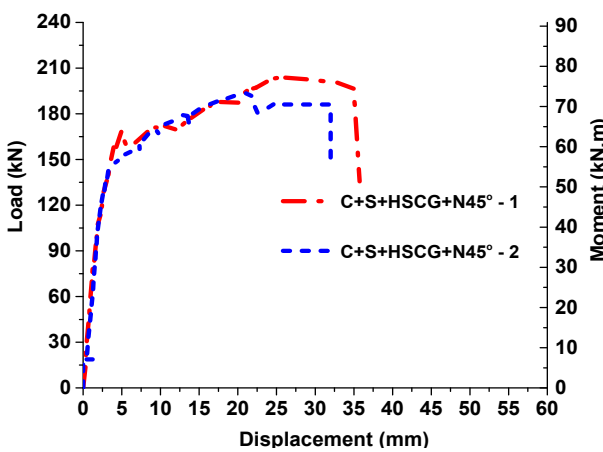

(c)

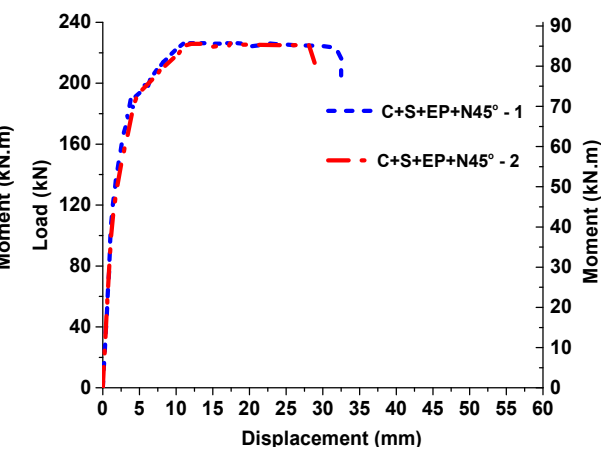

(b)

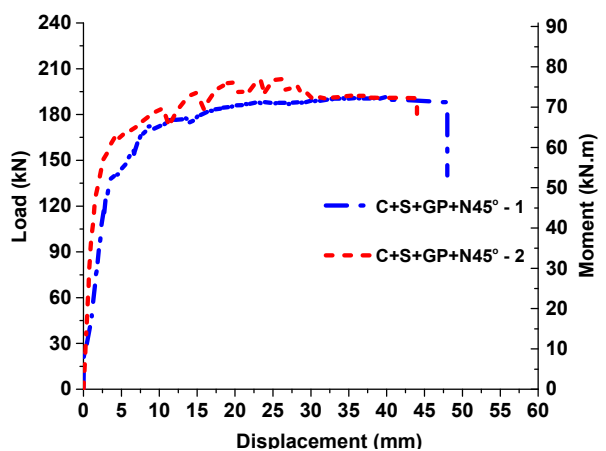

(d)

Figure 10. Load-Displacement behavior of stirrup beams with bonding materials. (a) Control beam; (b) Epoxy bonded specimen; (c) HSCG bonded specimen and (d) GP bonded specimen. 
Table 3. Test results of prestressed concrete beams under shear.

\begin{tabular}{|c|c|c|c|c|c|c|c|c|}
\hline Specimen ID & $\begin{array}{c}\text { Load @ First Crack } \\
(\text { (kN) }\end{array}$ & $\begin{array}{l}\text { Displ. @ First Crack } \\
(\mathrm{mm})\end{array}$ & Peak Load (kN) & $\begin{array}{c}\text { \% Increase in Peak } \\
\text { Load }\end{array}$ & $\begin{array}{l}\text { Displacement at } \\
\text { Peak Load }(\mathrm{mm})\end{array}$ & $\begin{array}{l}\text { Energy Absorption } \\
\text { (kN.mm) }\end{array}$ & $\begin{array}{l}\text { Ultimate Displ. } \\
(\mathrm{mm})\end{array}$ & $\begin{array}{l}\text { Increase in Ultimate } \\
\text { Disp.(mm) }\end{array}$ \\
\hline Control-1 & 100 & 1.69 & 152 & \multirow[t]{2}{*}{ - } & 4.4 & 2740 & 24.0 & \multirow[t]{2}{*}{-} \\
\hline Control-2 & 100 & 1.48 & 135 & & 3.6 & 2875 & 30.0 & \\
\hline $\mathrm{C}+\mathrm{EP}+\mathrm{N} 45^{\circ}-1$ & 130 & 2.04 & 238 & \multirow{2}{*}{56.2} & 28.5 & 7152 & 34.1 & \multirow{2}{*}{35.6} \\
\hline $\mathrm{C}+\mathrm{EP}+\mathrm{N} 45^{\circ}-2$ & 100 & 1.38 & 211 & & 21.5 & 7430 & 39.2 & \\
\hline $\mathrm{C}+\mathrm{CG}+\mathrm{N} 45^{\circ}-1$ & 120 & 2.98 & 204 & \multirow{2}{*}{30.5} & 22.1 & 6997 & 46.9 & \multirow{2}{*}{45.2} \\
\hline $\mathrm{C}+\mathrm{CG}+\mathrm{N} 45^{\circ}-2$ & 110 & 2.68 & 171 & & 5.2 & - & 31.4 & \\
\hline $\mathrm{C}+\mathrm{GP}+\mathrm{N} 45^{\circ}-1$ & 120 & 1.38 & 211 & \multirow{2}{*}{44.4} & 25.2 & 7812 & 42.2 & \multirow{2}{*}{66.7} \\
\hline $\mathrm{C}+\mathrm{GP}+\mathrm{N} 45^{\circ}-2$ & 120 & 1.65 & 204 & & 20.5 & 8764 & 48.1 & \\
\hline $\mathrm{C}+\mathrm{S}-1$ & 110 & 2.21 & 204 & \multirow[t]{2}{*}{-} & 24.8 & 6894 & 39.4 & \multirow[t]{2}{*}{ - } \\
\hline$C+S-2$ & 110 & 2.25 & 190 & & 18.9 & 4793 & 30.2 & \\
\hline $\mathrm{C}+\mathrm{S}+\mathrm{EP}+\mathrm{N} 45^{\circ}-1$ & 110 & 1.04 & 226 & \multirow{2}{*}{14.8} & 12.1 & 6800 & 28.5 & \multirow{2}{*}{-14.0} \\
\hline $\mathrm{C}+\mathrm{S}+\mathrm{EP}+\mathrm{N} 45^{\circ}-2$ & 120 & 1.54 & 226 & & 11.3 & 5953 & 32.5 & \\
\hline $\begin{array}{c}\mathrm{C}+\mathrm{S}+\mathrm{CG}+ \\
\mathrm{N} 45^{\circ}-1\end{array}$ & 120 & 2.35 & 194 & \multirow[t]{2}{*}{1.6} & 20.9 & 5397 & 32.1 & \multirow[t]{2}{*}{-2.6} \\
\hline $\begin{array}{c}\mathrm{C}+\mathrm{S}+\mathrm{CG}+ \\
\mathrm{N} 45^{\circ}-2\end{array}$ & 120 & 2.44 & 205 & & 25.9 & 6303 & 35.7 & \\
\hline $\mathrm{C}+\mathrm{S}+\mathrm{GP}+\mathrm{N} 45^{\circ}-1$ & 110 & 2.06 & 203 & \multirow{2}{*}{0.6} & 26.4 & 8066 & 44.0 & \multirow{2}{*}{32.2} \\
\hline $\mathrm{C}+\mathrm{S}+\mathrm{GP}+\mathrm{N} 45^{\circ}-2$ & 120 & 1.45 & 192 & & 37.5 & 8380 & 48.0 & \\
\hline
\end{tabular}




\subsection{Overall Load-Displacement Behavior with and without Stirrups}

The overall behavior of PSC beams is illustrated in Figures 11 and 12. In figures, set I and II refers to two similar specimens tested under same series. The results are presented to avoid for easy understanding. NSM strengthening with different bonding materials was highly effective in improving the peak resistance of PSC beams without vertical stirrups. Moreover, the strengthening also contributed to the improvement of ultimate displacement and converting the failure mode from predominantly shear to flexure (except HSCG mortar). HSCG mortar did not possess sufficient resistance in preventing the shear cracks propagating through them and resulting in failure of specimens in a diagonal shear tension failure mode. Epoxy resin exhibited excellent bonding properties, thus improving the overall behavior in terms of strength and ultimate displacement by $56.2 \%$ and 35.6 , respectively. GP mortar also had adequate resistance in restraining the shear crack and converted the failure mode from diagonal shear tension to flexure. The provision of stirrups in the beam has provided enough shear resistance and helped in converting the failure mode from diagonal shear tension mode to flexure mode. It is worth mentioning that the presence of stirrups contributed to the shear resistance of the beam making the NSM strengthening scheme somewhat less efficient. The NSM strengthening using inorganic bonding materials produced marginal improvement in strength. However, the GP mortar had good shear resistance converting the shear failure to flexure and thereby having increased displacement at the failure by $32.2 \%$. The NSM strengthening using epoxy improved the strength by about $14.8 \%$ with the reduction in the ultimate displacement of $14 \%$.

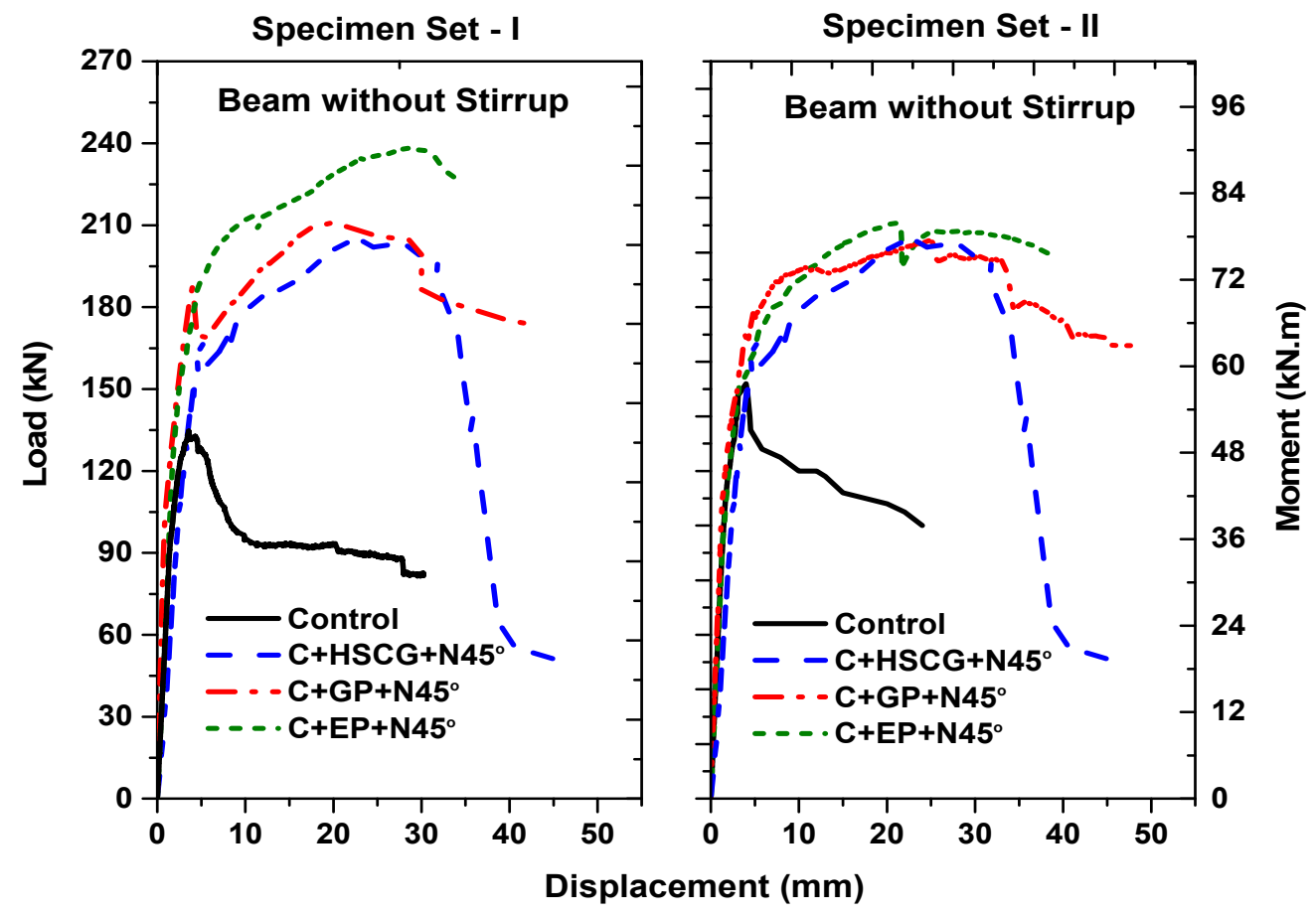

Figure 11. Overall behavior of control beams with different bonding materials. 


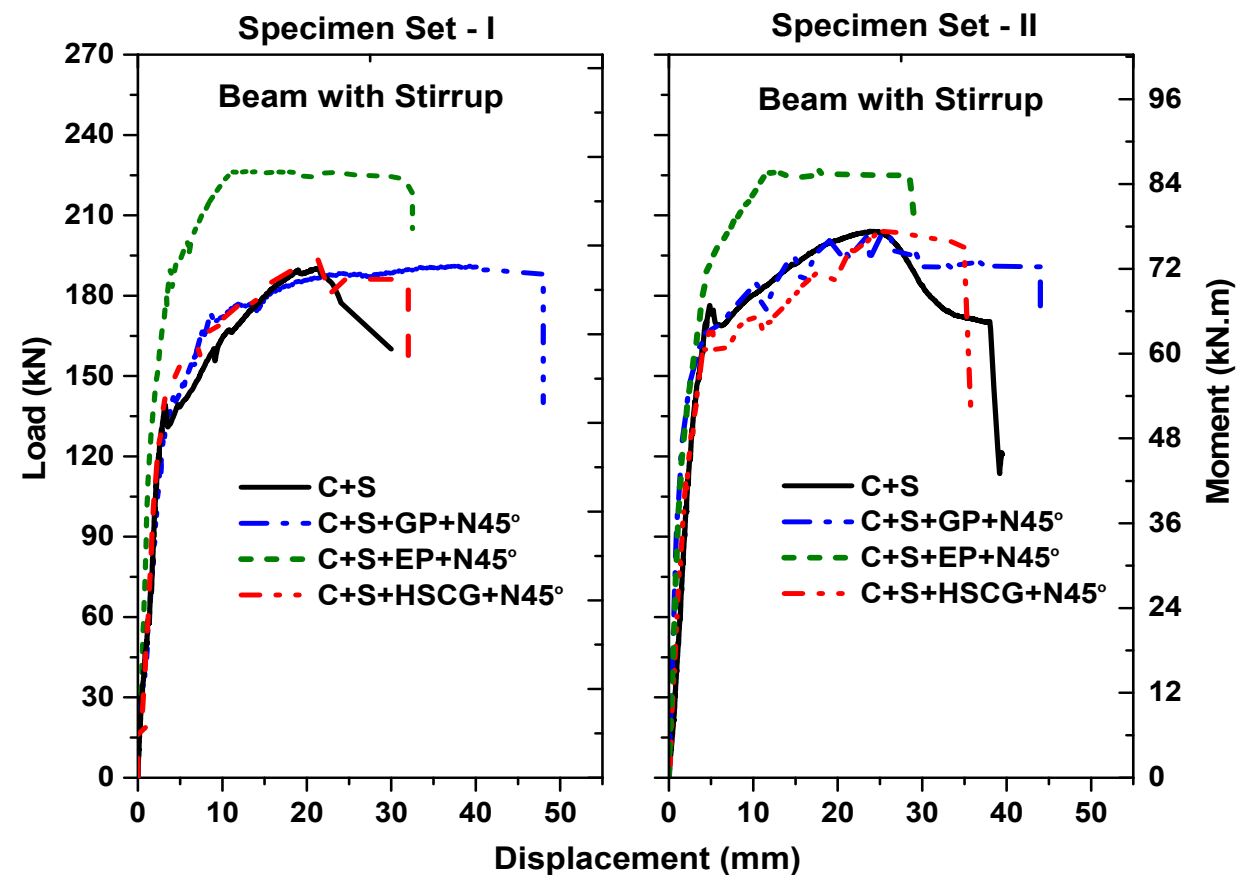

Figure 12. Overall behavior of stirrup beams with different bonding materials.

\subsection{Load-Strain Behavior}

The behavior of load-strand strain of PSC beams with and without vertical stirrups is shown in Figure 13. The prestressing strands used do not possess a well-defined yield point. Hence, the value of yield strain is considered to be $9000 \mu \mathrm{m} / \mathrm{m}$ [5-7]. The initial strain measured during the pre-tensioning process was found to be $4200 \mu \mathrm{m} / \mathrm{m}$. The control specimen which do not have any stirrups in the test zone had a strand strain of about $7500 \mu \mathrm{m} / \mathrm{m}$. It is clear from Figure 13, that the strands in control specimens with different bonding materials had the failure strain value close to the yield strain of prestressing strands. This is due to the effective contribution of strands and FRP laminates under shear. Their contribution reduces due to the presence of stirrups which is highly significant under shear than the strands and FRP. It is worth mentioning that the prestressing strands did not reach the yield strain in none of the specimens due to the predominant shear dominant behavior.

The load-CFRP strain behavior of strengthened PSC beams is shown in Figure 14. The rupture strain of FRP laminates is calculated from the corresponding ultimate stress and elastic modulus values obtained from the tension test results. The rupture strain of CFRP laminates is measured to be $1.3 \%$. NSM strengthening with epoxy as bonding material resulted in providing most efficient shear resistance by undergoing higher value of strains in both the beams with and without stirrups. This can be attributed to its excellent bond strength with the concrete and FRP than the other bonding materials. HSCG bonded specimen had lower strain value due to early debonding of FRP laminates. The maximum CFRP laminate strain value of HSCG bonded specimens was nearly $3000 \mu \mathrm{m} / \mathrm{m}$. The GP mortar had a failure strain of nearly $6000 \mu \mathrm{m} / \mathrm{m}$ showing a better performance than the HSCG specimens. 


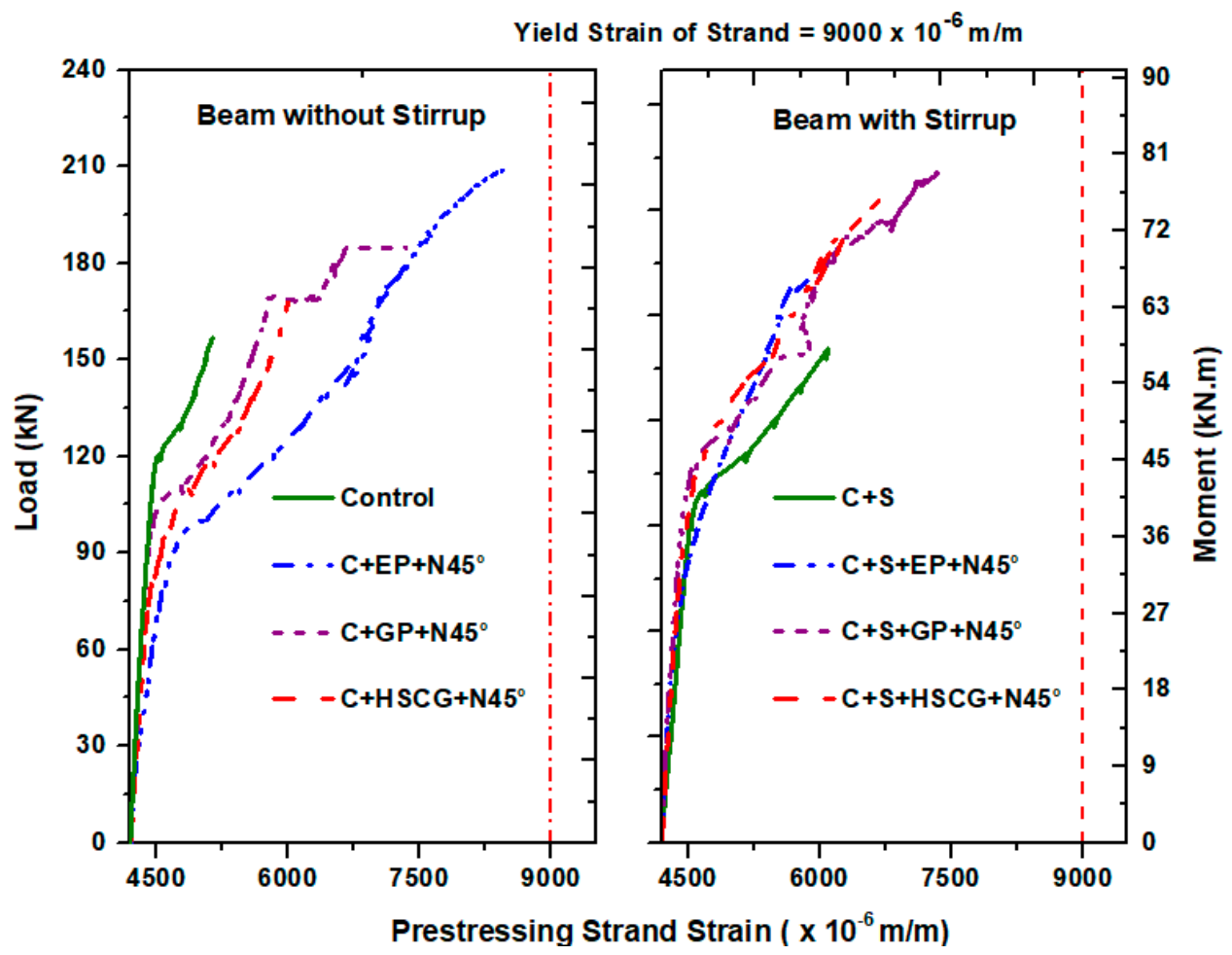

Figure 13. Load—strand strain behavior of beams with different bonding materials.

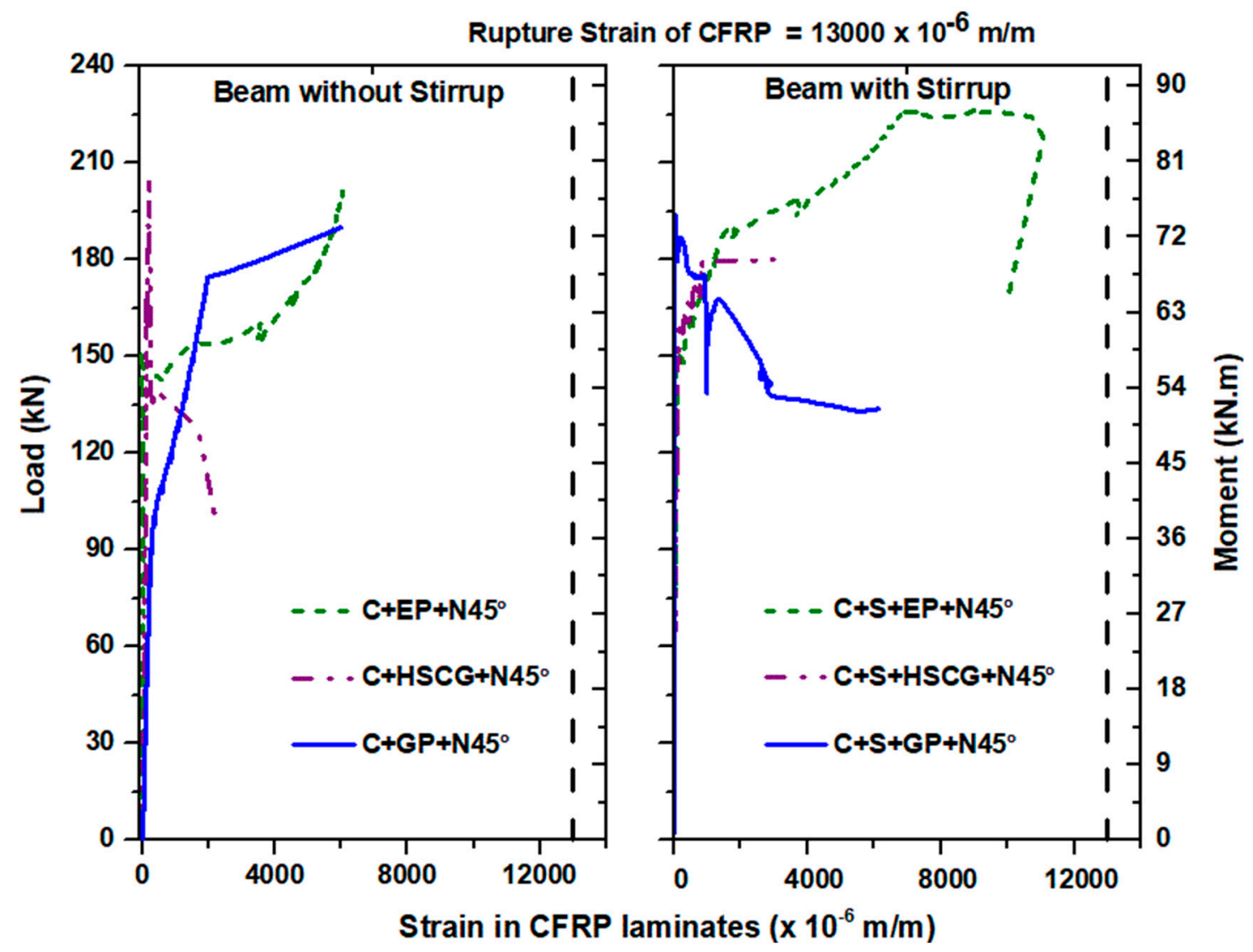

Figure 14. Load-FRP strain behavior of beams with different bonding materials. 
It is worth mentioning that the strains measured on the concrete surface using the LVDT rosette arrangements shall be used to determine the principal strains. Using three LVDTs from the rosette arrangement (i.e., vertical, horizontal and diagonal), the principal tensile and compression strains shall be determined. Moreover, the top and bottom strains obtained from the horizontal LVDTs shall be used to estimate the sectional curvature. The expressions used for calculating the principal strains and curvature are given in Equations (5) and (6) respectively.

$$
\begin{gathered}
\varepsilon_{1,2}=\left(\frac{\varepsilon_{x}+\varepsilon_{y}}{2}\right) \pm \frac{1}{\sqrt{2}} \times \sqrt{\left(\varepsilon_{\mathrm{x}}-\varepsilon_{\mathrm{d}}\right)^{2}+\left(\varepsilon_{y}-\varepsilon_{\mathrm{d}}\right)^{2}} \\
\Phi=\frac{\varepsilon_{t}+\varepsilon_{c}}{h}
\end{gathered}
$$

For a few tested specimens, the entire response for comparing the principal strains and curvature were not captured due to the instrumentation error (Slip of LVDTs). Hence, these comparisons were not presented as a part of this work.

\subsection{Failure Modes of PSC Beams with Different Bonding Materials}

The failure mode of prestressed concrete beams with and without vertical stirrups is illustrated in Figure 15. The control beams had initial crack below the point of load application. A shear crack occurred in the test zone when the load reached close to the peak load. The shear cracks propagated further and widened and the specimen failed finally due to diagonal shear tension mode. The propagation of shear crack propagation was effectively restrained by the NSM strengthening of CFRP laminates at $45^{\circ}$ orientation with epoxy as the bonding material. NSM strengthening also changed the failure from shear to flexure dominant mode (Figure 15). Specimens with HSCG as bonding material had the initiation and propagation of shear cracks at the peak load. At higher load levels, the shear cracks propagated across the laminates and the specimen failed due to shear tension. The final failure of the beams was initiated by debonding of FRP indicating the faster degradation of bond strength between the HSCG material and the NSM laminates at higher loads. Performance of specimens with GP mortar as bonding material was similar to that of HSCG. The NSM laminates restrained the shear cracks for beams with GP mortar. The shear cracks also originated between the NSM laminates at higher load levels (Figure 15). The beam also failed in flexure mode indicating the effectiveness of GP mortar as the bonding material for NSM strengthening.

Figure 15 highlights the mode of failure of control and NSM strengthened specimens with stirrups. The specimens with shear reinforcement $(C+S)$ had initial cracking due to flexure and then failed due to combined shear and flexure mode effects. It is worth mentioning that the beams with no stirrups failed in a brittle shear dominant mode. The propagation of shear cracks was effectively restrained by the presence of NSM laminates and stirrups for beams with epoxy as the bonding material. Once the beam reached its ultimate capacity, the shear crack developed adjacent to the NSM laminates and propagated towards the compression side. Due to the provision of stirrups and NSM laminates, the failure mode changed from brittle shear to less brittle flexure-shear. The crack width also reduced and led to better aggregate shear interlock and an overall improvement in the shear behavior of the beam. The PSC beams with HSCG and GP mortar as the bonding material for NSM configuration had first-cracking in flexure. With the increase in applied load, these flexure cracks converted to flexure-shear cracks. The increase in shear crack width was arrested by the NSM laminates leading to flexure dominant failure mode. The beams had predominantly flexural cracks and exhibited a better ductility. HSCG specimens failed due to flexure-shear whereas the GP specimens failed due to flexure exhibiting larger strain values at failure. 


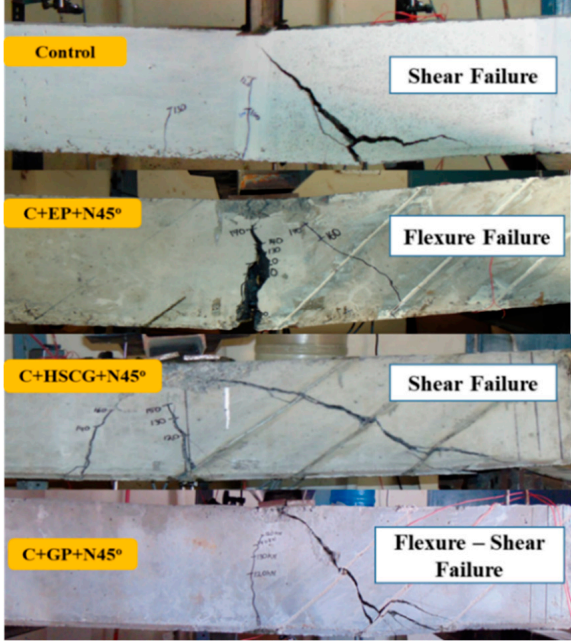

(a)

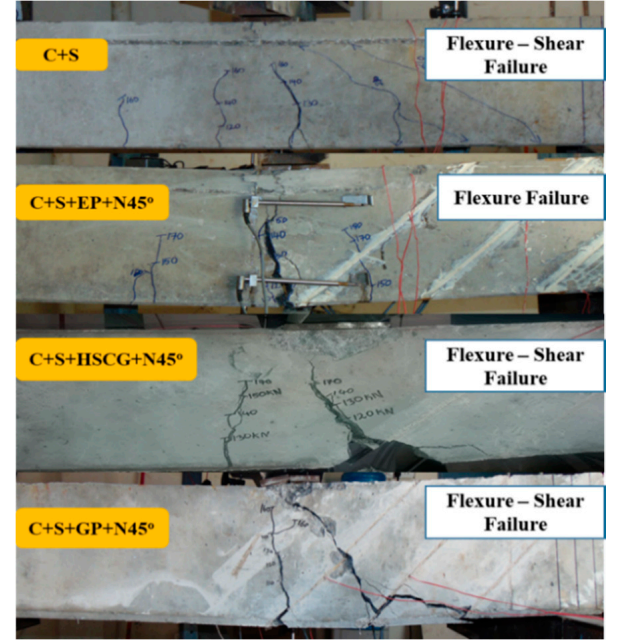

(b)

Figure 15. Failure mode of beams with different bonding materials. (a) Beams with no stirrups and (b) Beam with stirrups.

\subsection{Stiffness at Cracking and Energy Absorption}

The value of energy absorption for the specimens can be calculated by integrating the area under the load-displacement curve until the ultimate displacement. The strain energy absorption of beams with different bonding materials is compared in Figure 16. The value of stiffness at the level of cracking can be determined from the ratio of the cracking load to the displacement at the same load. The values of energy absorbed and stiffness at cracking are documented in Table 3. The control specimens with shear reinforcement had energy absorption of about two times that that of the beams without vertical stirrups. This is mainly due to the change in failure mode from brittle shear to ductile flexure-shear as a result of the effective contribution of shear reinforcement. This is vice versa in the case of NSM shear strengthened specimens. It also signifies that NSM CFRP laminates become less efficient when the stirrups are provided in the shear dominant zone. It is worth mentioning that the provision of shear reinforcement (stirrup) was alone able to prevent the diagonal shear failure. Thus, the contribution of NSM laminates shear resistance is expected to reduce in the beams with stirrups. The specimens with GP mortar as the bonding material had a better value of cracking stiffness than the other bonding materials.

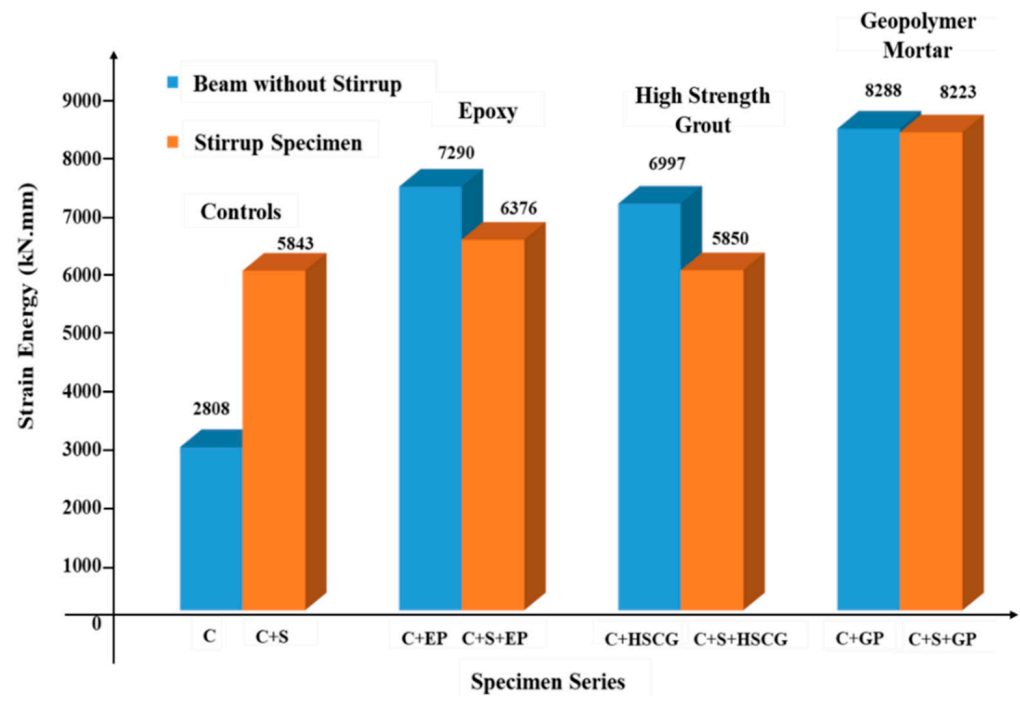

Figure 16. Strain energy absorption for NSM strengthened beams with different bonding materials. 


\section{Conclusions}

Sixteen precast prestressed concrete beams were tested with and without NSM shear strengthening of CFRP laminates using different bonding materials. Bond tests were also carried out for assessing the bond performance of different materials. The following major conclusions can be drawn from this experimental work:

- Bond (pull-out) tests for NSM FRP laminates were carried out using different bonding materials. Epoxy had the highest bond strength, followed by high strength cement grout and geopolymer mortar.

- NSM strengthening using epoxy as bonding material resulted in good improvement in terms of peak load capacity, by $56.2 \%$ and $14.8 \%$, for control specimens with and without stirrups, respectively.

- NSM shear strengthening of PSC beams using HSCG as bonding material improved the peak strength of beams without stirrups. However, it resulted only in marginal improvement of strength in the presence of stirrups.

- NSM strengthening of PSC beams using geopolymer as bonding material improved the peak shear strength and ultimate displacement of beams without stirrups by $44.4 \%$ and $66.7 \%$, respectively. However, it resulted in marginal improvement of strength and good improvement in ultimate displacement (32.2\%) in the presence of stirrups.

- Only a marginal difference in structural performance was observed between the geopolymer and high strength cement grout in NSM shear strengthening. Therefore, other factors such as availability, cost, and long-term durability shall be weighed while choosing the bonding material in NSM shear strengthening.

- The NSM shear strengthening reduced the width of the diagonal cracks in the post-cracking response. The NSM shear strengthening with all the bonding materials reduced the concrete surface strains at all stages of the post-cracking behavior.

Author Contributions: V.S.K., M.C., S.S.P. and A.S. designed the test matrix. V.S.K. and M.C. performed the experiments. M.C. wrote the paper. S.S.P. and A.S. reviewed the paper. All authors have read and agreed to the published version of the manuscript.

Funding: FAST-Center for Sustainable Development project funded this research work.

Conflicts of Interest: The authors declare no conflict of interest.

Abbreviations
$\begin{array}{ll}\text { The following } & \text { symbols are used in this paper: } \\ \alpha & \text { Empirical parameter taken as } 0.315 \text { in bond strength } \\ \beta_{P}, \beta_{L} & \text { Parameters to calculate bond strength and debonding strain } \\ E_{P} & \text { Modulus of Elasticity of FRP laminates (MPa) } \\ \varepsilon_{1,2} & \text { Principal strains calculated from LVDT rosette } \\ \varepsilon_{\mathrm{x}, \mathrm{y}} & \text { Strains in horizontal and vertical direction from LVDT rosette } \\ \varepsilon_{\mathrm{c}} & \text { Horizontal strain measured in the compression side (Top) } \\ \varepsilon_{\mathrm{t}} & \text { Horizontal strain measured in the tension side (Bottom) } \\ \varepsilon_{\mathrm{d}} & \text { Diagonal strain measured from LVDT rosette arrangement } \\ t_{P} & \text { Thickness of FRP laminates (mm) } \\ b_{P} & \text { Width of FRP laminates (mm) } \\ b_{c} & \text { Width of cube specimen (mm) } \\ f_{c}{ }^{\prime} & \text { Compressive strength of the bonding material (MPa) } \\ L_{e} & \text { Effective bond length (mm) } \\ L & \text { Embedded length (mm) } \\ \Phi & \text { Curvature of the section (mm }{ }^{-1} \text { ) } \\ h & \text { Distance between the horizontal LVDTs (mm) }\end{array}$




\section{References}

1. Sharaky, I.A.; Torres, L.; Comas, J.; Barris, C. Flexural response of reinforced concrete beams strengthened with near surface mounting fiber reinforced polymer bars. Compos. Struct. 2014, 109, 8-22. [CrossRef]

2. Zhang, S.S.; Yu, T.; Chen, G.M. Reinforced concrete beams strengthened in flexure with near-surface mounted (NSM) CFRP strips: Current status and research needs. Compos. Part B Eng. 2017, 131, 30-42. [CrossRef]

3. Breveglieri, M.; Barros, J.A.O.; Dalfré, G.M.; Aprile, A. A parametric study on the effectiveness of the NSM technique for the flexural strengthening of continuous RC slabs. Compos. Part B Eng. 2013, 43, 1970-1987. [CrossRef]

4. De Lorenzis, L.; Teng, J.G. Near surface mounted fiber reinforced polymer reinforcement: An emerging technique for strengthening. Compos. Part B Eng. 2007, 38, 119-143. [CrossRef]

5. Kankeri, P.; Prakash, S.S. Experimental evaluation of bonded overlay and NSM GFRP bar strengthening on flexural behaviour of precast prestressed hollow core slabs. Eng. Struct. 2016, 120, 49-57. [CrossRef]

6. Pachalla, S.K.S.; Prakash, S.S. Effect of openings on the behaviour of PPHCS slabs under low and moderate shear. ACI Struct. J. 2017, 114, 1-10.

7. Pachalla, S.K.S.; Prakash, S.S. Efficient near-surface mounted CFRP strengthening of pretensioned hollow core slabs with opening: An experimental study. Compos. Struct. 2017, 162, 28-38. [CrossRef]

8. Yao, J.; Teng, J.G.; Chen, J.F. Experimental study on FRP-to-concrete bonded joints. Compos. Part B Eng. 2005, 36, 99-113. [CrossRef]

9. Islam, A.K.M. Effective methods of using carbon fiber reinforced polymer in shear strengthening of concrete girders. Eng. Struct. 2009, 31, 709-714. [CrossRef]

10. Rahal, K.N.; Rumaih, H.A. Tests on reinforced concrete beams strengthened in shear using Near Surface Mounted CFRP and steel bars. Eng. Struct. 2011, 33, 53-62. [CrossRef]

11. Pellegrino, C.; Modena, C. Fiber Reinforced Polymer shear strengthening of Reinforced Concrete beams with transverse steel reinforcement. J. Compos. Constr. 2002, 6, 104-111. [CrossRef]

12. Kuntal, V.S.; Chellapandian, M.; Prakash, S.S. Efficient near surface mounted CFRP shear strengthening of high strength prestressed concrete members-An experimental study. Compos. Struct. 2017, 180, 16-28. [CrossRef]

13. Dias, S.J.E.; Barros, J.A.O. New Shear Strengthening technique with CFRP laminates applied in high T cross section RC beam. Compos. Part B Eng. 2017, 114, 256-267. [CrossRef]

14. Barros, J.A.O; Dias, S.J.E.; Baghi, H.; Ventura-Gouveia, A. New shear strengthening configurations of Near-Surface Mounted CFRP laminates for RC beams. ACI Struct. J. 2016, 13, 1275-1286. [CrossRef]

15. Barros, J.A.O.; Dias, S.J.E. Near surface mounted CFRP laminates for shear strengthening of concrete beams. Cem. Concr. Compos. 2006, 28, 276-292. [CrossRef]

16. Ceroni, F. Experimental performances of reinforced concrete beams strengthened with FRP materials. Constr. Build. Mater. 2010, 24, 1547-1559. [CrossRef]

17. Rizzo, A.; De-Lorenzis, L. Behavior and capacity of reinforced concrete beams strengthened with NSM FRP reinforcement. Constr. Build. Mater. 2009, 23, 1555-1567. [CrossRef]

18. Mofidi, A.; Chaallal, O.; Chen, L.; Chao, Y. Investigation of near surface mounted for shear rehabilitation of reinforced concrete beams using fiber reinforced polymer composites. J.Compos. Constr. 2016, 20, 1-14. [CrossRef]

19. Rahman, M.M.; Jumat, M.Z.; Hosen, M.A.; Islam, A.B.M.S. Effect of adhesive replacement with cement mortar on NSM strengthened RC beam. Rev. La Construcción 2016, 15, 61-72. [CrossRef]

20. Al-Mahmoud, F.; Castel, A.; Francois, R.; Tourneur, C. Strengthening of RC members with near-surface mounted CFRP rods. Compos. Struct. 2009, 91, 138-147. [CrossRef]

21. Zhang, H.Y.; Hao, X.; Fan, W. Experimental study on high temperature properties of carbon fiber sheets strengthened concrete cylinders using geopolymer as adhesive. Procedia Eng. 2016, 135, 47-55. [CrossRef]

22. Al-Bayati, G.; Al-Mahaidi, R.; Kalfat, R. Experimental investigation into the use of NSM FRP to increase the torsional resistance of RC beams using epoxy resins and cement-based adhesives. Constr. Build. Mater. 2016, 124, 1153-1164. [CrossRef]

23. Hashemi, S.; Al-Mahaidi, R. Experimental and finite element analysis of flexural behavior of FRP-strengthened RC beams using cement-based adhesives. Constr. Build. Mater. 2012, 26, 268-273. [CrossRef] 
24. Al-Abdwais, A.; Al-Mahaidi, R. Modified cement-based adhesive for Near-surface mounted CFRP strengthening system. Constr. Build. Mater. 2016, 124, 794-800. [CrossRef]

25. Al-Abdwais, A. Near-surface mounted CFRP application on reinforced concrete members using modified cement-based adhesive. Ph.D. Thesis, Swinburne University of Technology, Melbourne, Australia, 2015.

26. Maranan, G.B.; Manalo, A.C.; Benmokrane, B.; Karunasena, W.; Mendis, P.; Nguyen, T.Q. Shear behaviour of geopolymer-concrete beams transversely reinforced with continuous rectangular GFRP composite spirals. Comp. Struct. 2018, 187, 454-465. [CrossRef]

27. Chalioris, C.E.; Kosmidou, P.K.; Papadopoulos, N.A. Investigation of a New Strengthening Technique for RC Deep Beams Using Carbon FRP Ropes as Transverse Reinforcements. Fibers. 2018, 6, 52. [CrossRef]

28. Chalioris, C.E.; Kytinou, V.K.; Voutetaki, M.E.; Papadopoulos, N.A. Repair of Heavily Damaged RC Beams Failing in Shear Using U-Shaped Mortar Jackets. Buildings 2019, 9, 146. [CrossRef]

29. Moradi, E.; Naderpour, H.; Kheyroddin, A. An experimental approach for shear strengthening of RC beams using a proposed technique by embedded through-section FRP sheets. Comp. Struct. 2020, 238, 111988. [CrossRef]

30. Chalioris, C.E.; Zapris, A.G.; Karayannis, G. U-Jacketing Applications of Fiber-Reinforced Polymers in Reinforced Concrete T-Beams against Shear-Tests and Design. Fibers 2020, 8, 13. [CrossRef]

31. Zheng, Y.; Zhou, Y.; Zhou, Y.; Pan, T.; Zhang, Q.; Liu, D. Cracking behavior of reinforced concrete beams strengthened with CFRP anchorage system under cyclic and monotonic loading. Eng. Struct. 2020, 207, 110222. [CrossRef]

32. Indian Standards 516. Methods of Test for Strength of Concrete; Amendment No. 2, Reprint 1993; Bureau of Indian Standards: New Delhi, India, 1959.

33. ASTM D3039. Standard Test Method for Tensile Properties of Polymer Matrix Composite Materials; ASTM 2000; ASTM International: West Conshohocken, PA, USA, 2017.

34. De-Lorenzis, L.; Nanni, A. Bond of near-surface mounted FRP rods to concrete. ACI Struct. J. 2002, 99, 123-132.

35. De-Lorenzis, L.; Rizzo, A.; Tegola, A.L. A modified pull-out test for bond of near-surface mounted FRP rods in concrete. Compos. Part B Eng. 2002, 33, 589-603. [CrossRef]

36. ASTM C1583. Standard test method for Tensile Strength of Concrete Surfaces and the Bond Strength or Tensile Strength of Concrete Repair and Overlay Materials by Direct Tension (Pull-off Method); ASTM International: West Conshohocken, PA, USA, 2017.

37. Teng, J.G.; Smith, S.T.; Yao, J.; Chen, J.F. Intermediate crack induced debonding in RC beams and slabs. Constr. Build. Mater. 2003, 17, 447-462. [CrossRef]

38. Bencardino, F.; Condello, A. Innovative solution to retrofit RC members: Inhibiting-repairing-strengthening (IRS). Constr. Build. Mater. 2016, 117, 171-181. [CrossRef]

39. ACI 440.2R. Guide for the Design and Construction of Externally Bonded FRP System for Strengthening Concrete Structures; ACI Committee 440; American Concrete Institute: Farmington Hills, MI, USA, 2017.

40. Kani, G. How safe are our large reinforced concrete beams? ACI Struct. J. 1967, 64, 128-141.

(C) 2020 by the authors. Licensee MDPI, Basel, Switzerland. This article is an open access article distributed under the terms and conditions of the Creative Commons Attribution (CC BY) license (http://creativecommons.org/licenses/by/4.0/). 